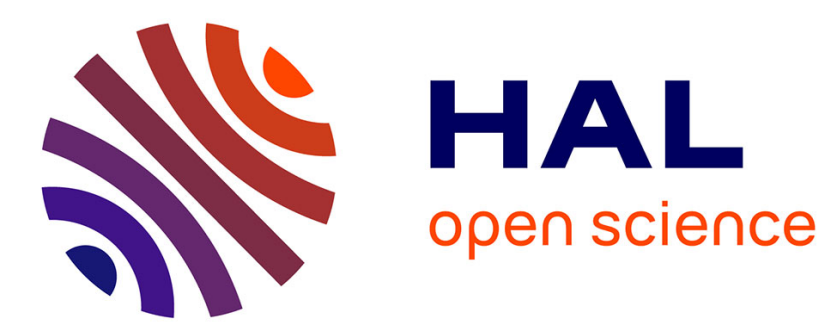

\title{
The Cellular Prion Protein and the Hallmarks of Cancer
} Sophie Mouillet-Richard, Alexandre Ghazi, Pierre Laurent-Puig

\section{To cite this version:}

Sophie Mouillet-Richard, Alexandre Ghazi, Pierre Laurent-Puig. The Cellular Prion Protein and the Hallmarks of Cancer. Cancers, 2021, 13 (19), pp.5032. 10.3390/cancers13195032 . hal-03379898

\section{HAL Id: hal-03379898 \\ https://hal.sorbonne-universite.fr/hal-03379898}

Submitted on 15 Oct 2021

HAL is a multi-disciplinary open access archive for the deposit and dissemination of scientific research documents, whether they are published or not. The documents may come from teaching and research institutions in France or abroad, or from public or private research centers.
L'archive ouverte pluridisciplinaire HAL, est destinée au dépôt et à la diffusion de documents scientifiques de niveau recherche, publiés ou non, émanant des établissements d'enseignement et de recherche français ou étrangers, des laboratoires publics ou privés. 


\title{
The Cellular Prion Protein and the Hallmarks of Cancer
}

\author{
Sophie Mouillet-Richard ${ }^{1, *(\mathbb{D})}$, Alexandre Ghazi ${ }^{1}$ and Pierre Laurent-Puig ${ }^{1,2}$ (D) \\ 1 Centre de Recherche des Cordeliers, Université de Paris, INSERM, Sorbonne Université, F-75006 Paris, France; \\ alexandre.ghazi@parisdescartes.fr (A.G.); pierre.laurent-puig@parisdescartes.fr (P.L.-P.) \\ 2 Department of Biology, Institut du Cancer Paris CARPEM, APHP, Hôpital Européen Georges Pompidou, \\ F-75015 Paris, France \\ * Correspondence: sophie.mouillet-richard@parisdescartes.fr
}

check for

updates

Citation: Mouillet-Richard, S.; Ghazi,

A.; Laurent-Puig, P. The Cellular

Prion Protein and the Hallmarks of

Cancer. Cancers 2021, 13, 5032.

https://doi.org/10.3390/

cancers13195032

Academic Editor: Richard Bayliss

Received: 8 September 2021

Accepted: 5 October 2021

Published: 8 October 2021

Publisher's Note: MDPI stays neutral with regard to jurisdictional claims in published maps and institutional affiliations.

Copyright: (c) 2021 by the authors. Licensee MDPI, Basel, Switzerland. This article is an open access article distributed under the terms and conditions of the Creative Commons Attribution (CC BY) license (https:/ / creativecommons.org/licenses/by/ $4.0 /)$.
Simple Summary: The cellular prion protein $\operatorname{PrP}^{\mathrm{C}}$ is best known for its involvement, under its pathogenic isoform, in a group of neurodegenerative diseases. Notwithstanding, an emerging role for $\mathrm{PrP}^{\mathrm{C}}$ in various cancer-associated processes has attracted increasing attention over recent years. $\mathrm{PrP}^{\mathrm{C}}$ is overexpressed in diverse types of solid cancers and has been incriminated in various aspects of cancer biology, most notably proliferation, migration, invasion and metastasis, as well as resistance to cytotoxic agents. This article aims to provide a comprehensive overview of the current knowledge of $\mathrm{PrPC}^{\mathrm{C}}$ with respect to the hallmarks of cancer, a reference framework encompassing the major characteristics of cancer cells.

\begin{abstract}
Beyond its causal involvement in a group of neurodegenerative diseases known as Transmissible Spongiform Encephalopathies, the cellular prion protein $\mathrm{PrP}^{\mathrm{C}}$ is now taking centre stage as an important contributor to cancer progression in various types of solid tumours. The prion cancer research field has progressively expanded in the last few years and has yielded consistent evidence for an involvement of $\mathrm{PrP}^{\mathrm{C}}$ in cancer cell proliferation, migration and invasion, therapeutic resistance and cancer stem cell properties. Most recent data have uncovered new facets of the biology of $\operatorname{Pr} \mathrm{P}^{\mathrm{C}}$ in cancer, ranging from its control on enzymes involved in immune tolerance to its radio-protective activity, by way of promoting angiogenesis. In the present review, we aim to summarise the body of literature dedicated to the study of $\mathrm{PrP}^{\mathrm{C}}$ in relation to cancer from the perspective of the hallmarks of cancer, the reference framework defined by Hanahan and Weinberg.
\end{abstract}

Keywords: cellular prion protein; cancer hallmarks; signalling pathways

\section{Introduction}

The cellular prion protein $\mathrm{PrP}^{\mathrm{C}}$ was discovered in the mid-1980s as the normal counterpart of the scrapie prion protein, denoted $\mathrm{PrP}^{\mathrm{Sc}}$, itself responsible for the development of a group of fatal neurodegenerative diseases known as Transmissible Spongiform Encephalopathies or prion diseases [1]. $\mathrm{PrP}^{\mathrm{C}}$, encoded by the PRNP gene located on chromosome 20 in humans, is a ubiquitous protein that is highly conserved from fish to mammals [2]. It is a small glycoprotein of 253 amino acids subject to various types of post-translational modifications: removal of a $\mathrm{N}$-terminal signal peptide responsible for the trafficking of the protein to the endoplasmic reticulum for subsequent maturation, replacement of the C-terminus with a glycosyl-phosphatidylinositol (GPI) moiety that allows $\mathrm{PrP}^{\mathrm{C}}$ anchoring at the extracellular plasma membrane, formation of a disulfide bridge and potential N-glycosylation on two Asparagine residues (reviewed in [3]). Beyond being majorly GPI-anchored at the cell membrane, $\mathrm{PrP}^{\mathrm{C}}$ may additionally exist as two topological transmembrane variants with either the $\mathrm{N}$-terminus $(\mathrm{CtmPrP})$ or $\mathrm{C}$-terminus $(\mathrm{NtmPrP})$ portion in the cytosol, possibly accounting for the interaction with cytosolic partners [3]. From a structure-function point of view, $\operatorname{PrP}^{\mathrm{C}}$ is composed of a $\mathrm{N}$-terminal, intrinsically disordered domain, also referred to as "flexible tail", a central hydrophobic domain and a 
C-terminal globular domain (Figure 1). A notable feature within the N-terminal domain is the presence of four histidine-containing octapeptide tandem repeats, which are involved in the binding of divalent ions such as copper or zinc, themselves promoting the endocytosis of $\mathrm{PrP}^{\mathrm{C}}$ [4]. In addition to full-length isoforms, several proteolytic processes can generate various truncated or soluble forms of $\mathrm{PrP}^{\mathrm{C}}$ (reviewed in [5]). First, the so-called alpha-cleavage, occurring at position $111 / 112$, generates a $\mathrm{N}$-terminal fragment termed N1 and a C-terminal, GPI-anchored fragment termed C1 (Figure 1). This alpha-cleavage occurs under physiological conditions and influences the endocytosis of $\mathrm{PrP}^{\mathrm{C}}$ as well as its interaction with diverse partners [5]. The beta-cleavage generating N2 and C2 fragments takes place within the octarepeat region (Figure 1). It is mostly described as a reactive oxygen species-dependent reaction sustaining the protective role of $\operatorname{PrP}^{\mathrm{C}}$ against oxidative stress [5]. Finally, a far C-terminal cleavage is responsible for the production of "shed $\operatorname{PrP}^{\mathrm{C}}$ ", which nearly encompasses the full sequence of $\operatorname{PrP}^{\mathrm{C}}$ (Figure 1). Shed $\operatorname{PrP}^{\mathrm{C}}$ is, however, distinct from soluble $\mathrm{PrP}^{\mathrm{C}}$ as it results from the phospholipase-C mediated hydrolysis of the GPI anchor [5]. Altogether, miscellaneous glycosylation and proteolytic processes in fine generate a variety of $\mathrm{PrP}^{\mathrm{C}}$ isoforms that may underlie its wide range of functions [6]. One should further bear in mind that the various soluble isoforms, N1, N2, shed $\operatorname{PrP}^{\mathrm{C}}$ as well as phospholipase-C-released $\operatorname{PrP}^{\mathrm{C}}$, have the capacity to signal to neighbouring cells (see [5] for review). This also holds true for exosomal $\mathrm{PrP}^{\mathrm{C}}$, as will be discussed below.

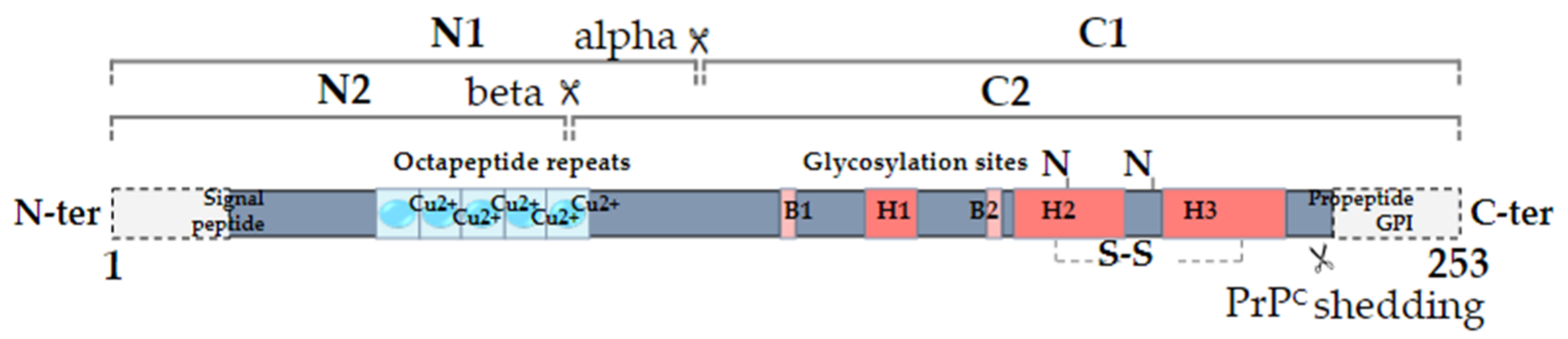

Figure 1. Secondary structure of human $\mathrm{PrPC}$. The alpha-cleavage occurs at position 110/111 and generates the $\mathrm{N} 1$ and $\mathrm{C} 1$ fragments. The beta-cleavage occurs in the vicinity of octapeptide repeats, which bind copper ions, and generates the N2 and $\mathrm{C} 2$ fragments. $\mathrm{PrP}^{\mathrm{C}}$ can also be shed from the plasma membrane through the action of ADAM10. The alpha helices $(\mathrm{H})$ and beta sheets (B) are indicated (adapted from [7]).

The variety of $\operatorname{PrP}^{\mathrm{C}}$ isoforms may explain why $\operatorname{PrP}^{\mathrm{C}}$ has been ascribed a plethora of functions, ranging from broad roles in the physiology of the central nervous system, resistance to various types of stresses, cell fate and differentiation, cell adhesion and cell signalling [6]. Unravelling the physiological roles exerted by $\operatorname{PrP}^{\mathrm{C}}$ has long emerged as a powerful strategy to understand how the corruption of these functions may contribute to pathological contexts, not only prion diseases [7] but also other disorders, including Alzheimer's disease, immune disorders or cancer [8]. Obviously, the research dedicated to prion and cancer has lagged behind that of neurodegeneration, but this field is now becoming the focus of growing interest. We here chose to provide a comprehensive review of the current knowledge relating to $\mathrm{PrP}^{\mathrm{C}}$ in cancer through the lens of the hallmarks of cancer. As such, the contribution of $\operatorname{PrP}^{\mathrm{C}}$ to the emergence and/or maintenance of cancer stem cell properties or the potential therapeutic strategies to target this protein in cancer will not be discussed here and have been covered by several reviews [9-12]. The hallmarks of cancer are a reference framework introduced by Hanahan and Weinberg over 20 years ago [13] and further refined in 2011 [14]. It summarises the fundamental capacities endowing cancer cells with the ability to develop and escape control by the organism. In this review, we will summarise the overall data relating to the biology of $\operatorname{PrPC}^{\mathrm{C}}$ in cancer according to each hallmark, except the enabling replicative immortality hallmark due to a lack of data on this axis. We further highlight some findings pertaining to the physiological function of $\mathrm{PrP}^{\mathrm{C}}$ and discuss their potential implications in the field of cancer. 


\section{Sustaining Proliferative Signalling}

Since sustained proliferative capacity arguably represents one of the most fundamental traits of cancer cells, the contribution of $\operatorname{Pr} P^{C}$ to cancer cell proliferation has been extensively studied. The first demonstration that $\operatorname{PrPC}^{\mathrm{C}}$ drives the proliferation of cancer cells was brought by the team of Daiming Fan using the SGC7901 and AGS gastric cancer cell lines [15]. In the low $\operatorname{PrP}^{\mathrm{C}}$-expressing SGC7901 cells, PrP overexpression promoted an increase in cell proliferation in vitro, as well as tumour growth in xenografted nude mice [15]. To the opposite, $\operatorname{PrP}^{\mathrm{C}}$ silencing in the high $\operatorname{PrP}^{\mathrm{C}}$-expressing AGS cell line triggered a reduction in their proliferative index [15]. At a mechanistic level, $\mathrm{PrP}^{\mathrm{C}}$ was shown to foster the transition from the G0/G1 to the S phase and to transcriptionally control the expression of Cyclin D1 via the PI3/AKT signalling pathway. From a structure-function point of view, it is interesting to note that the action of $\mathrm{PrPC}^{\mathrm{C}}$ requires the presence of the $\mathrm{N}$-terminal domain of the protein [15], in line with the importance of this region in the coupling of $\mathrm{PrP}^{\mathrm{C}}$ to PI3K/AKT signalling in non-tumoral cells [16].

Similarly, $\mathrm{Li}$ and colleagues documented a reduction in cell proliferation and in vivo tumour growth upon $\mathrm{PrP}^{\mathrm{C}}$ silencing in the pancreatic cancer cell lines BxPC3 and Pan 02.03 [17]. In a follow-up study based on the same cellular models together with the Capan-1 pancreatic cell line, $\mathrm{PrP}^{\mathrm{C}}$ was found to control the levels of Ki67 [18], a key marker of cell proliferation [19]. Interestingly, the decrease in cell proliferation observed after $\mathrm{PrP}^{\mathrm{C}}$ silencing in Capan-1 cells was abrogated upon a concomitant overexpression of the activated form of NOTCH1 [18]. This observation has to be brought together with the $\mathrm{PrP}^{\mathrm{C}}$-dependent control on the Notch pathway that we documented in neural stem and progenitor cells [20]. A correlation between $\mathrm{PrP}^{\mathrm{C}}$ and Ki67 levels was also reported by Lopes et al. in a large cohort of patients with glioblastoma [21]. As with gastric and pancreatic cell lines, the latter study demonstrated a pro-proliferative action of $\operatorname{PrP}^{\mathrm{C}}$ in the U87 glioma cell line and corresponding xenografts, which was dependent upon the interaction of $\mathrm{PrP}^{\mathrm{C}}$ with its ligand STI1 [21]. The proliferative role of $\mathrm{PrP}^{\mathrm{C}}$ in glioblastoma was also confirmed in U87 cells grown as spheres to mimic glioblastoma stem cells [22] as well as in primary tumour cells [9]. In addition, $\mathrm{PrP}^{\mathrm{C}}$ expression was reported to vary according to the cell cycle in U87 glioma cells with significantly higher levels in the G2/M versus G1/S phase [23]. The $\mathrm{PrP}^{\mathrm{C}}$-dependent control of proliferation was also exemplified in schwannoma [24] and colorectal cancer [25-30]. In the context of colorectal cancer, we notably brought to light a $\mathrm{PrP}^{\mathrm{C}}$-dependent activation of the integrin linked kinase (ILK) that relays its control on cell proliferation [26]. Adding another layer of complexity to the picture, Yun et al. recently reported that the proliferation of various colorectal cancer cells can be sustained by exosomes derived from the same cells grown under hypoxia in a $\mathrm{PrP}^{\mathrm{C}}$-dependent manner [31]. In this setting, two non-mutually exclusive mechanisms may be at play: the proliferation of recipient cells may be directly regulated by exosomal $\operatorname{PrPC}$, the level of which is increased following hypoxia [31], or it may additionally depend upon other exosomal proteins whose abundance in exosomes is influenced by the expression of $\mathrm{PrP}^{\mathrm{C}}$ in cancer cells. In this respect, it is also worth noting that $\mathrm{PrP}^{\mathrm{C}}$ regulates the balance between exosome biogenesis and autophagy [32]. Thus, we may surmise that high $\operatorname{PrP}^{\mathrm{C}}$-expressing cancer cells produce abundant levels of exosomes, enriched in $\operatorname{PrP}^{\mathrm{C}}$, that may sustain their proliferation in an autocrine and paracrine manner, especially in a hypoxic environment.

We many finally note that the $\operatorname{PrP}^{\mathrm{C}}$-dependent regulation of proliferation in the context of cancer may be viewed as a gain of its normal physiological function resulting from its overexpression. Indeed, the contribution of $\mathrm{PrPC}^{\mathrm{C}}$ to normal cell proliferation has been extensively documented (reviewed in [6]), most notably in the context of stem cells (reviewed in [11]). The physiological $\mathrm{PrP}^{\mathrm{C}}$-dependent regulation of proliferation may involve a modulation of the Epidermal Growth Factor Receptor (EGFR) activity as described by Llorens et al. [33]. Incidentally, $\mathrm{PrP}^{\mathrm{C}}$ and EGFR were shown to co-localise and to interact, as inferred by co-immunoprecipitation experiments, in the HT29 colorectal cell line [34]. These overall observations warrant investigating the signalling pathways 
through which $\operatorname{PrP}^{\mathrm{C}}$ sustains the proliferation of cancer cells and its potential functional interactions with growth factor receptors.

\section{Evading Growth Suppressors}

This hallmark corresponds to the ability of cancer cells to circumvent anti-growth signals [14]. They may do so by bypassing the activity of suppressors of proliferation such as TP53 and RB, encoding p53 and the retinoblastoma-associated protein, respectively, evading mechanisms of contact inhibition and/or corrupting anti-growth signalling circuitries such as the Transforming Growth Factor $\beta$ (TGF $\beta$ ) pathway. Although a direct contribution of $\mathrm{PrP}^{\mathrm{C}}$ to growth suppressors evasion has yet to be fully investigated, some observations are worth considering.

First, several studies have uncovered a modulation of p53 expression and activity by $\mathrm{PrP}^{\mathrm{C}}$ and its proteolytic fragments (reviewed in [35]). On the one hand, the full length $\mathrm{PrP}^{\mathrm{C}}$ was shown to up-regulate p53 activity and mRNA levels in neuronal cells upon exposure to the apoptotic inducer staurosporine, thereby sensitising cells to cell death [36]. This also holds true for the cleaved $\mathrm{C} 1$ fragment of $\mathrm{PrP}^{\mathrm{C}}$, as shown in HEK293 cells [37]. On the other hand, the $\mathrm{N} 1$ soluble fragment of $\operatorname{PrP}^{\mathrm{C}}$ was found to exert an opposite effect on p53 and to protect cells from the full length and $\mathrm{C} 1 \mathrm{PrP}^{\mathrm{C}}$-mediated potentiation of cell death [38]. Importantly, this set of studies, as well as others [39,40], indicated that overexpressed $\operatorname{PrP}^{\mathrm{C}}$ has no impact on the p53 pathway in basal conditions, i.e., in the absence of pro-apoptotic signals.

Nevertheless, an activation of p53 signalling was reported upon PrP overexpression in skeletal muscle [41]. In a more cancer-relevant context, Liang et al. documented that $\operatorname{PrP}^{\mathrm{C}}$ silencing promotes an increase in the expression levels of p53 in the gastric cancer cell line AGS, while an opposite effect was obtained upon $\operatorname{PrP}^{\mathrm{C}}$ overexpression [42]. Thus, until now, these scarce studies have provided only a glimpse of the potential regulation of p53 by $\operatorname{PrP}^{\mathrm{C}}$, which may notably depend upon the relative abundance of its different isoforms.

Regarding contact inhibition, an interesting observation is the upregulation of $\operatorname{PrP}^{\mathrm{C}}$ in various types of Merlin-deficient tumours, including schwannoma and mesothelioma [24]. Merlin, encoded by the neurofibromatosis type 2 (NF2) gene, is a well-described regulator of cell-cell attachment, whose loss of function allows cells to evade contact inhibition [43]. Of note, we recently demonstrated that $\mathrm{PrP}^{\mathrm{C}}$ levels positively control the phosphorylation of NF2 on serine 518, itself negatively regulating NF2 activity, in colorectal cancer [26]. Mechanistically, $\operatorname{PrP}^{\mathrm{C}}$ operates via ILK [26], previously described as an upstream regulator of the NF2-Hippo pathway in various types of cancer cells [44]. Accordingly, we documented that the $\operatorname{PrP}^{\mathrm{C}}$-ILK module promotes the activation of YAP/TAZ [26], the two transcriptional effectors of the Hippo pathway, which play a key role in promoting the poor-prognosis mesenchymal subtype of colorectal cancer [28,45]. Since YAP/TAZ are major orchestrators of organ growth and contact inhibition [46], their upstream regulation by $\operatorname{PrP}^{\mathrm{C}}$ clearly delineates a link between $\mathrm{Pr}^{\mathrm{C}}$ and contact inhibition. Furthermore, because NF2 controls the cell surface availability of various growth factor receptors [43], it will be interesting for future studies to evaluate the impact of its negative regulation by $\operatorname{PrP}^{\mathrm{C}}$ on growth factor receptor signalling.

Finally, regarding TGF $\beta$, we recently demonstrated that $\operatorname{PrP}^{C}$ controls the soluble levels of TGF $\beta$ in the supernatant of colorectal cancer cells [28]. Conversely, $\operatorname{PrP}^{\mathrm{C}}$ levels are increased in response to TGF $\beta$ [28]. Although the mechanisms involved still require further investigation, we were able to show that the $\operatorname{PrP}^{\mathrm{C}}-\mathrm{TGF} \beta$ axis contributes to the expression of several markers that specify the mesenchymal subtype of colorectal cancer, including that of ZEB1, a master regulator of Epithelial to Mesenchymal Transition (EMT) [28]. These observations call for a better understanding of the interplay between $\operatorname{PrP}^{C}$ and TGF $\beta$, considering the major role played by TGF $\beta$ not only in the poor prognosis subgroup of colorectal cancer [47] but more widely in various aspects of high-grade malignancy across cancer [48]. 


\section{Resisting Cell Death}

Resistance to apoptosis was the first hallmark to be connected with $\operatorname{PrP}^{\mathrm{C}}$ nearly 20 years ago, as PRNP transcripts were found to be upregulated in adriamycin-resistant SGC7901 gastric cancer cells as compared to the parental cell line [49]. That elevated $\mathrm{PrP}^{\mathrm{C}}$ may confer resistance to anticancer agents was soon confirmed by the demonstration of a causal relationship between increased $\mathrm{PrP}^{\mathrm{C}}$ expression and resistance to tumour necrosis factor- $\alpha$ (TNF $\alpha)$ in the MCF7 breast cancer cell line [50]. The involvement of $\mathrm{PrP}^{\mathrm{C}}$ in the resistance of cancer cells to cell death-inducing signals has been extensively studied by employing diverse experimental paradigms. The first set of data provided evidence for an upregulation of $\mathrm{PrPC}^{\mathrm{C}}$ expression in drug-resistant contexts, as in a seminal Zhao study [49]. For instance, PRNP gene expression [51] and $\mathrm{PrP}^{\mathrm{C}}$ protein levels [52] were found to be upregulated in adriamycin-resistant MCF7 breast cancer cells, as well as in SNU-5C colorectal cancer cells resistant to 5-fluorouracil (5-FU) or oxaliplatin [53]. Zhuang et al. further showed a dose-dependent increase in $\mathrm{PrP}^{\mathrm{C}}$ expression in U87 and U251 glioblastoma cells in response to temolozomide [23]. Moreover, we reported that high expression levels of $\operatorname{PrP}^{\mathrm{C}}$ are associated with 5-FU resistance in a panel of colorectal cancer cell lines [28]. On the other hand, $\mathrm{PrP}^{\mathrm{C}}$ overexpression was reported to induce resistance to adriamycin, vincristine, etoposide, 5-FU and cisplatin in SGC7901 gastric cancer cells [54] and resistance to TNF $\alpha$ [30] or adriamycin [25] in LS174 colorectal cancer cells. Conversely, silencing of $\mathrm{PrP}^{\mathrm{C}}$ increased the sensitivity of MKN28 gastric cancer cells to adriamycin, vincristin, etoposide, 5-FU and cisplatin [55] and that of 5-FU-resistant SNU-5C/FUR [56] or MDST8 [28] colorectal cancer cells to 5-FU. It also cancelled the protection of hypoxia against TRAIL-mediated cell death in HCT116 colorectal cancer cells, while $\mathrm{PrP}^{\mathrm{C}}$ overexpression conferred resistance to TRAIL-induced cytotoxicity in normoxic conditions [57]. These observations are summarised in Figure 2.

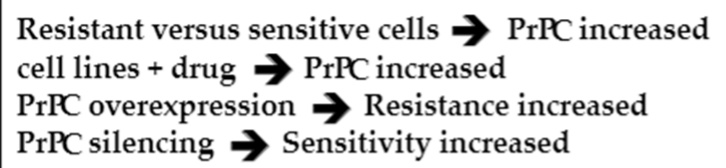

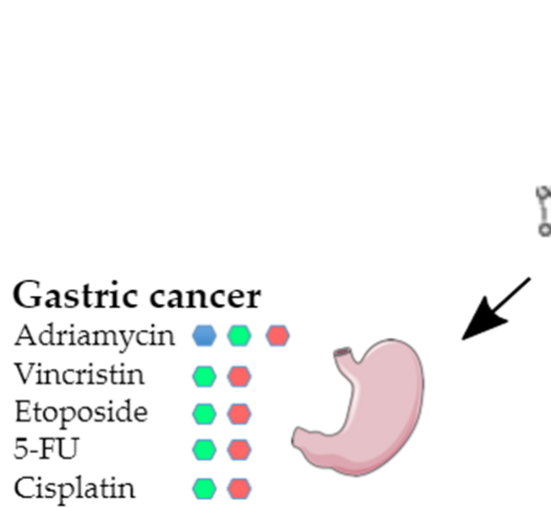

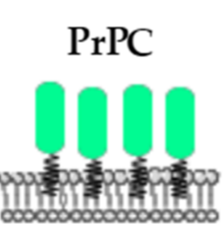

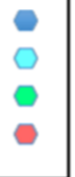

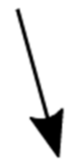

\section{Glioblastoma \\ Temolozomide}

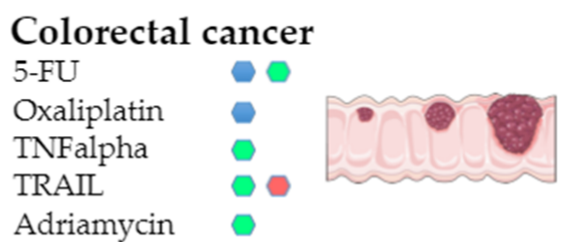

Figure 2. Summary of the data supporting a link between $\operatorname{PrP}^{\mathrm{C}}$ expression and resistance to cytotoxic agents.

From a translational perspective, it is interesting to note that the relationship between $\operatorname{PrP}^{\mathrm{C}}$ levels and chemoresistance was confirmed in patients. Indeed, an increased $\operatorname{PrP}^{\mathrm{C}}$ expression was reported in recurrent versus primary lesions of patients with glioblastoma, following combined temolozomide and radiation therapy [23]. In the same line, Yun et al. 
reported that plasma levels of $\operatorname{PrP}^{\mathrm{C}}$ are higher in colorectal cancer patients having received chemotherapy versus untreated patients [31]. Moreover, high $\mathrm{PrPC}^{\mathrm{C}}$ levels in gastric cancer patients were found to be associated with a poor response to chemotherapy [58].

At a molecular level, $\mathrm{PrP}^{\mathrm{C}}$ may promote chemoresistance through the upregulation of MDR1, which encodes the P-glycoprotein, a transporter responsible for the efflux of anticancer drugs, as shown in SGC7901 gastric cancer cells [54]. The $\operatorname{PrP}^{\mathrm{C}}$-dependent control on MDR1 appears to be mediated by the PI3K-Akt pathway [59] and to necessitate the octarepeat-rich $\mathrm{N}$-terminal domain of $\operatorname{PrP}^{\mathrm{C}}$ [60], although the deletion of a single octarepeat appears without effect [61]. The recruitment of the PI3K-Akt cascade downstream from $\mathrm{PrP}^{\mathrm{C}}$ may rely upon its interaction with the $37 \mathrm{kD}$ laminin receptor precursor protein (37LRP), as suggested by Luo et al. [62]. A different, non-mutually exclusive mechanism is the positive regulation of the anti-apoptotic effector Bcl2, which may not only occur in gastric [42,54,58], breast [51] and glioma [63] cancer cells but is also a well-described pathway relaying the cell-survival physiological activity of $\operatorname{PrP}^{\mathrm{C}}$ (reviewed in [64]) and was even recently documented in the context of liver metabolism [65]. Other effects of $\mathrm{PrP}^{\mathrm{C}}$ on apoptotic effectors include the upregulation of survivin, cIAP-1 and XIAP levels in colorectal cancer cells [25] or the sequestration of the pro-apoptotic factor Par4 in glioblastoma cells [23]. Finally, Wiegmans et al. described a novel mechanism whereby soluble $\mathrm{PrP}^{\mathrm{C}}$ promotes the resistance of breast cancer cells to adriamycin through the direct binding and sequestration of the drug [66].

Beyond conferring resistance to anticancer drugs, $\operatorname{PrPC}^{\mathrm{C}}$ was recently reported to protect breast and colorectal cancer cells from irradiation-induced toxicity [67]. Accordingly, PRNP expression levels were found to be increased following radiation treatment of breast or rectal tumours [67]. As with other $\mathrm{PrPC}^{\mathrm{C}}$-related processes, the radioprotective function of $\mathrm{PrP}^{\mathrm{C}}$ is not restricted to cancer cells but was also exemplified in hematopoietic progenitor cells [68]. PrPC actually appears to confer a broad resistance to genotoxic stress, in part by potentiating the activity of the APE1 endonuclease, a major player in DNA repair [69].

Overall, the relationship between $\mathrm{PrP}^{\mathrm{C}}$ and resistance to cell death in cancer is multifaceted and can be viewed as an exacerbation of one of its diverse physiological functions.

\section{Inducing Angiogenesis}

The link between $\operatorname{PrP}^{\mathrm{C}}$ and angiogenesis emerged almost two decades ago with several studies showing that $\mathrm{PrP}^{\mathrm{C}}$ is expressed and released by endothelial cells and that its levels are increased after ischemic injury (reviewed in [70]). These observations were subsequently refined with the demonstration that $\operatorname{PrP}^{\mathrm{C}}$-deficient mice submitted to cerebral ischemia exhibit poorer recovery as compared with wild-type mice, including reduced neo-angiogenesis [71]. In that study, the authors suggested that $\operatorname{PrP}^{\mathrm{C}}$ operates, at least in part, by preventing the degradation of HIF1 $\alpha$ by the proteasome (see Figure 3) [71].

In line with this, Alfaidy et al. suggested that $\mathrm{PrP}^{\mathrm{C}}$ is involved in placental angiogenesis by controlling the proliferation, migration and tube-like organisation of trophoblastic cells [72]. This study further showed an upregulation of $\operatorname{PrP}^{\mathrm{C}}$ in response to hypoxia [72], which is now quite well established under various paradigms (reviewed in [73]). The HIF1 $\alpha$-dependent control on $\operatorname{PrPC}^{\mathrm{C}}$ expression actually extends to the stabilisation of the protein through the sequestration of the E3 ligase GP78 by hypoxia-induced HSPA1L (Figure 3), as shown by Lee et al. in colorectal cancer cells [56]. Very recently, these data were expanded with the demonstration that the levels of $\operatorname{PrP}^{\mathrm{C}}$ released in exosomes of colorectal cancer cells are increased under hypoxia [31]. In accordance with the broad role of hypoxia in tumour-associated angiogenesis [74] and the contribution of exosomes to this process [75], Yun et al. found that exosomes derived from colorectal cancer cells grown under hypoxia promote the proliferation, migration, invasion and permeability of human umbilical vein endothelial cells (HUVECs) (Figure 3) [31]. This seminal study provides the first direct evidence for a contribution of $\mathrm{PrP}^{\mathrm{C}}$ to cancer-associated angiogenesis. Other indirect support is brought by the downstream effectors of $\operatorname{PrP}^{C}$ in cancer cells. For instance, we showed that, in colorectal cancer, $\operatorname{PrP}^{\mathrm{C}}$ controls the expression of 
Platelet-Derived Growth Factor C (PDGFC) (Figure 3) [28], a stimulator of angiogenesis [76]. It also activates YAP and TAZ [28], the two main effectors of the Hippo pathway, which have been shown to promote vascular mimicry, a process whereby cancer cells themselves, instead of endothelial cells, form angiogenic tubules to supply blood to the tumour [77].

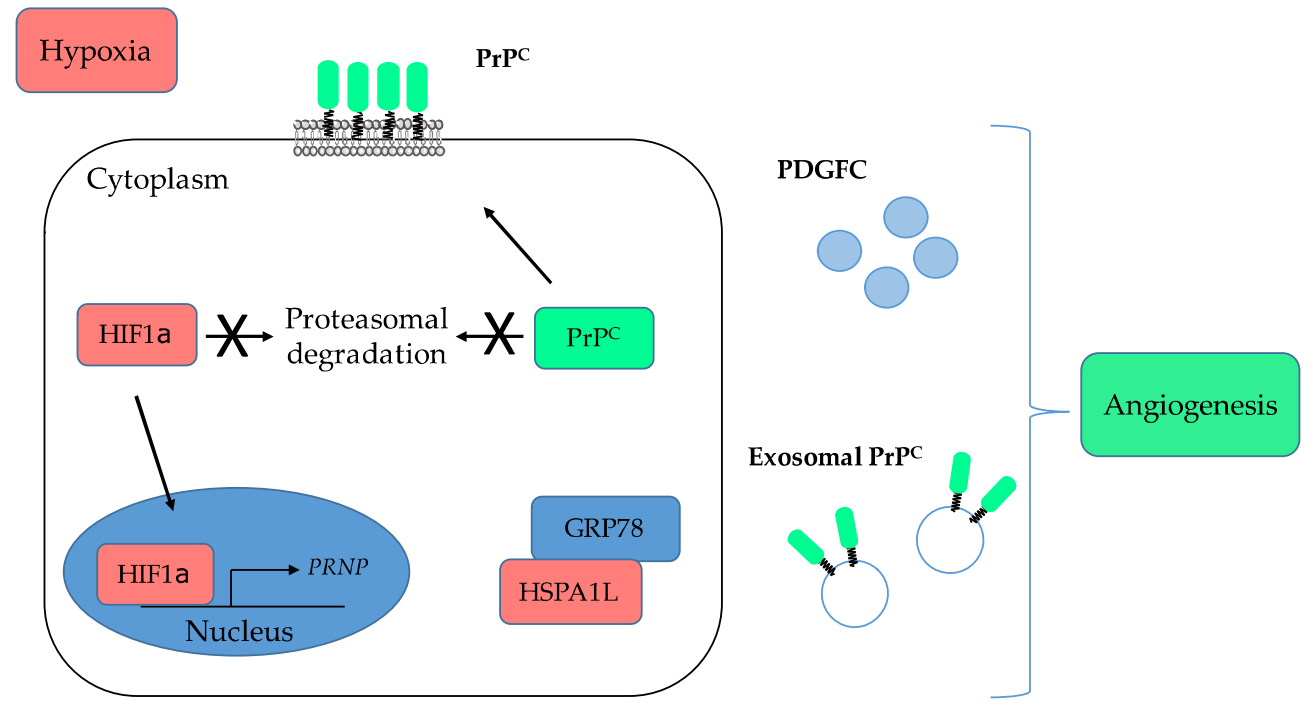

Figure 3. Summary of the interplay between $\operatorname{PrP}^{\mathrm{C}}$ and hypoxia and of the contribution of $\operatorname{PrP}^{\mathrm{C}}$ to angiogenesis. $\mathrm{PrPC}^{\mathrm{C}}$ is induced under ischemic conditions and prevents the degradation of $\mathrm{HIF} 1 \alpha$ by the proteasome. On the other hand, under hypoxia, HIF1 $\alpha$ promotes the transcription of the PRNP gene, favours the sequestration of the GRP78 E3-ligase, leading to enhanced $\operatorname{PrP}^{\mathrm{C}}$ protein stability, and is associated with enhanced release of exosomal $\mathrm{PrP}^{\mathrm{C}} \cdot \mathrm{PrP}^{\mathrm{C}}$ may further sustain angiogenesis by controlling the levels of PDGFC.

Finally, we may note that the $\operatorname{PrP}^{\mathrm{C}}$ paralogue Doppel has been incriminated in both developmental [78] and cancer-associated angiogenesis [79]. As Doppel resembles the C-terminal moiety of $\operatorname{PrP}^{\mathrm{C}}$ [80], whether $\operatorname{PrP}^{\mathrm{C}}$ or its cleaved fragments recapitulate the functional interaction with VEGFR2 reported for Doppel in tumour endothelial cells [79] seems worth investigating.

Altogether, the contribution of $\mathrm{PrP}^{\mathrm{C}}$ to cancer-associated angiogenesis is only beginning to be unveiled and will certainly be an important axis for future research.

\section{Activating Invasion and Metastasis}

A most notable hallmark of cancer cells is their ability to disseminate to distant organs. One major biological process sustaining invasion and metastasis is a transcriptional program referred to as EMT, whereby cells lose cell-cell contacts and acquire the capacity to migrate and degrade the surrounding matrix for dissemination [81]. The EMT program is orchestrated by major transcription factors, such as SNAIL, SLUG, TWIST, ZEB1 or ZEB2 [81]. There are multiple lines of evidence indicating that $\operatorname{PrP}^{\mathrm{C}}$ promotes the invasion and migration of cancer cells and controls some EMT-associated features. Indeed, silencing of $\mathrm{PrP}^{\mathrm{C}}$ in adryamicin-resistant $\mathrm{MCF}$ breast cancer cells reduces their invasion and migration, as well as the expression of two metalloproteases MMP2 and MMP9 [52]. Conversely, $\mathrm{PrP}^{\mathrm{C}}$ overexpression in MCF7 cells enhances their invasion and migration as well as the expression and activity of MMP9 [82]. Similarly, depleting $\operatorname{PrP}^{\mathrm{C}}$ in U87 glioma cells reduces their migration on laminin [22]. In the Capan-1 pancreatic cell line, Wang et al. found that the reduction in cell migration induced by the depletion of $\mathrm{PrP}^{\mathrm{C}}$ was rescued upon overexpression of the activated form of NOTCH1 [18]. In addition, $\mathrm{PrP}^{\mathrm{C}}$-silencing in SGC7901 or MKN45 gastric cancer cells caused a reduction in their invasion, their expression of MMP11, as well as their ability to metastasise to the liver after tail vein injection [83]. In the context of lung cancer, higher $\operatorname{PrP}^{\mathrm{C}}$ levels were measured in a panel of invasive 
versus non-invasive lung cancer cell lines [84]. Furthermore, $\mathrm{PrP}^{\mathrm{C}}$ was shown to control the invasive and migratory properties of CL1-5 cells via a JNK pathway and the knock-down of $\mathrm{PrP}^{\mathrm{C}}$ reduced their metastatic potential in vivo [84]. Likewise, various studies based on gain and loss of function experiments in colorectal cancer cell lines confirmed the proinvasive and pro-migratory action of $\operatorname{PrP}^{\mathrm{C}}[25,26,85]$. In line with this, Go et al. depicted an increased invasion and migration in the $\operatorname{PrP}^{\mathrm{C}}$-positive versus the $\operatorname{PrP}^{\mathrm{C}}$-negative fraction of 5-FU resistant SNU-5C/FUR cells [27]. Finally, the presence of $\operatorname{PrP}^{\mathrm{C}}$ together with that of the cancer stem cell marker CD44 at the cell surface of primary colorectal cancer cells was found to control their migration in vitro as well as their metastatic potential after injection in the cecal wall [86]. Several studies have further documented a link between $\mathrm{PrP}^{\mathrm{C}}$ and EMT. Thus, in primary colorectal cancer cells, $\mathrm{PrP}^{\mathrm{C}}$ was found to control the expression of the EMT transcription factor TWIST and that of N-cadherin while repressing that of E-cadherin [86]. Similar findings were obtained with HT29 colorectal cancer cells grown under hypoxia [56]. Likewise, we documented that $\operatorname{PrP}^{\mathrm{C}}$ controls the expression of the EMT transcription factor ZEB1 in colorectal cancer cell lines and that PRNP gene expression is significantly correlated with an EMT signature in both colorectal cancer patients and cell panels [28]. These overall findings are summarised in Figure 4 (top panel).

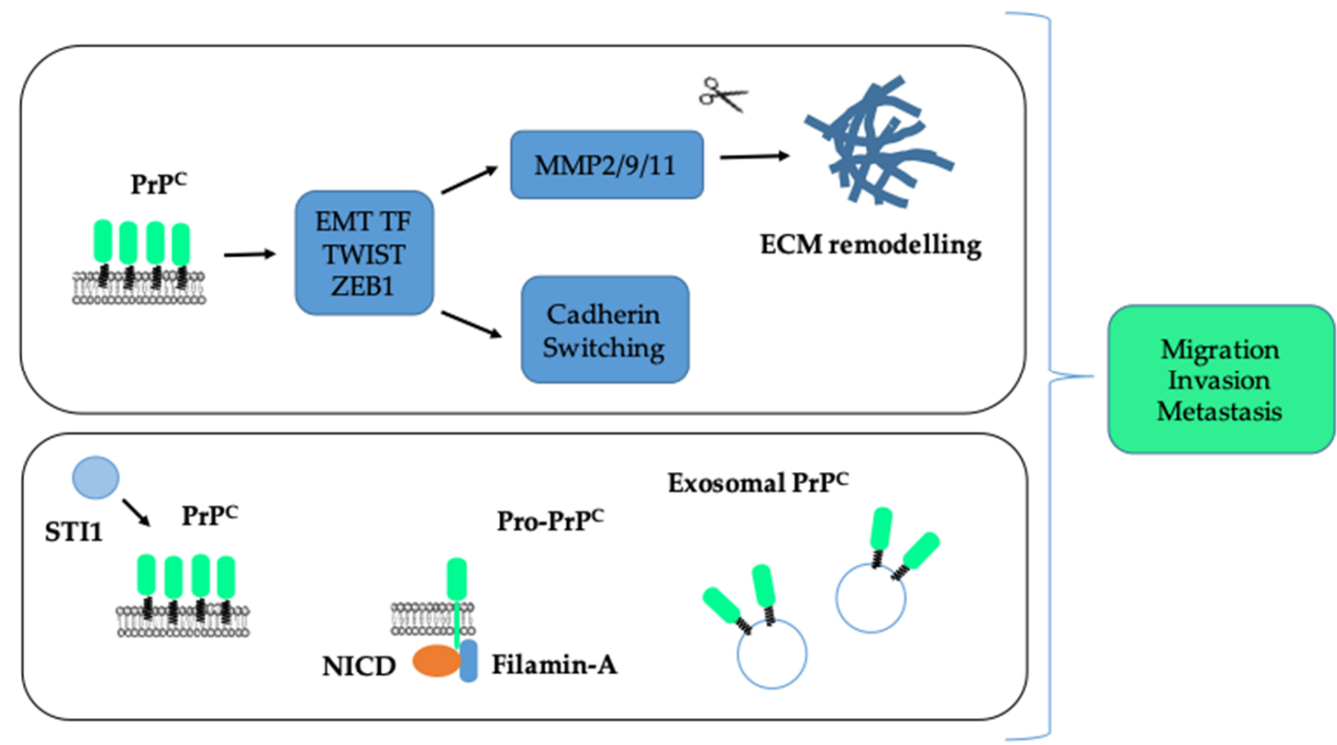

Figure 4. Elevated $\mathrm{PrP}^{\mathrm{C}}$ is associated with increased invasion and migration of cancer cells and metastasis. $\mathrm{PrP}^{\mathrm{C}}$ promotes an upregulation of EMT transcription factors (EMT TF), a switch from E-cadherin to N-cadherin expression as well as an induction of matrix metalloproteases, themselves fostering the remodelling of the extracellular matrix (ECM) (top panel). This action may be fostered by the interaction between $\operatorname{PrP}^{\mathrm{C}}$ and its ligand STI1. It is also supported by pro-PrPC, through its interaction with Filamin-A and the active cleaved fragment of Notch, NICD (Notch Intra Cellular Domain) or by exosomal $\mathrm{PrPC}^{\mathrm{C}}$ (bottom panel).

At a mechanistic level, several findings are worth noting. Lacerda et al. found that the $\mathrm{PrP}^{\mathrm{C}}$ pro-invasive action in colorectal cancer cells depends upon its interaction with its ligand STI1 [87]. Moreover, we recently highlighted the importance of the $\mathrm{PrP}^{\mathrm{C}}$-ILK coupling in the invasive and migratory properties of the MDST8 colorectal cancer cell line [26]. On the other hand, in melanoma cells, where $\mathrm{PrP}^{\mathrm{C}}$ is mainly found as a pro$\mathrm{PrP}$ isoform retaining its C-terminus instead of a GPI anchor, invasion and migration depends upon the interaction of pro-PrP with Filamin-A [88], which was shown to form a complex with pro-PrP and NOTCH1 in pancreatic cancer cells [18]. Yun et al. further demonstrated that exosomes derived from various colorectal cancer cells grown under hypoxia can sustain their own invasion and migration in a $\operatorname{PrP}^{\mathrm{C}}$-dependent manner (see Figure 4, bottom panel) [31]. 
From a clinical point of view, several studies have depicted a correlation between high levels of tumour PrPC — as inferred through immuno-histochemistry —and metastasis in patients with breast [89], gastric [83,90] and colorectal $[31,56,86]$ cancer. In the same line, Lin et al. depicted increased levels of tumour $\operatorname{PrP}^{C}$ in patients with invasive versus in situ lung adenocarcinoma [84]. Moreover, in colorectal cancer, we reported an enrichment in the expression of the PRNP gene in the mesenchymal subtype [28], itself associated with increased progression to advanced stages [91]. We further documented that plasma levels of $\mathrm{PrP}^{\mathrm{C}}$ have prognostic value in terms of disease control in metastatic colorectal cancer patients [28]. Thus, $\mathrm{PrPC}^{\mathrm{C}}$ is unambiguously associated with this hallmark of cancer.

\section{Reprogramming of Energy Metabolism (Emerging Hallmark)}

Metabolic reprogramming features as one of the emerging hallmarks of cancer [14], which has taken centre stage over the past decade [92]. It is clear that studies addressing the question as to whether $\operatorname{PrP}^{\mathrm{C}}$ may influence the metabolism of cancer cells are very scarce. Most data come from the work by Li et al. who found a regulation of the expression of GLUT1, encoding the glucose transporter 1, downstream from $\mathrm{PrP}^{\mathrm{C}}$ in the DLD-1 colorectal cancer cell line [29]. Accordingly, the authors demonstrated that $\operatorname{PrPC}^{\mathrm{C}}$ depletion reduces glucose uptake and the glycolytic rate of colorectal cancer cells [29]. From a translational point of view, it is worth noting that the expression levels of $\mathrm{PrPC}^{\mathrm{C}}$ and GLUT1 were correlated in colorectal cancer patients [29]. These findings actually recall the identification of both $\mathrm{PrPC}^{\mathrm{C}}$ and GLUT1 as specific cell-surface biomarkers of the adenoma-to-carcinoma transition in colorectal cancer [93]. Aside from cancer, the link between $\mathrm{PrP}^{\mathrm{C}}$ and glucose uptake is further strengthened by the work of Ashok et al. based upon a comparison of various tissues of mice deficient in $\operatorname{PrPC}^{\mathrm{C}}$ versus their wildtype counterparts for the expression of glucose transporters [94]. However, in apparent contradiction with the data obtained in cancer cells, the absence of $\mathrm{PrPC}^{\mathrm{C}}$ was associated with increased GLUT1, GLUT2 or GLUT3 levels according to the tissue-brain, retina or liver-considered [94]. Changes in the expression of the mono-carboxylate transporters MCT1 and MCT4, involved in the transport of lactate and pyruvate, were also observed in the brains of mice lacking $\operatorname{Pr} \mathrm{P}^{\mathrm{C}}$, with positive or negative regulations depending on the cerebral region considered [95]. In this respect, it is interesting to note that $\operatorname{PrPC}^{\mathrm{C}}$ was found to control the uptake of lactate by astrocytes through the interaction with $\mathrm{Na}+\mathrm{K}+\mathrm{ATPase}$, the driving force for MCT1 activity [96]. Other points of interest include the interaction between $\operatorname{PrP}^{C}$ and the lactate dehydrogenase isoforms LDH-A and LDH-B, which were uncovered through systematic proteomic assays for $\mathrm{PrP}^{\mathrm{C}}$ partners [97-99]. $\mathrm{PrP}^{\mathrm{C}}$ was later shown to potentiate the activity of $\mathrm{LDH}$ in the hypoxic brain, which may contribute to the protective role for $\operatorname{PrP}^{C}$ against stress [100]. Other $\operatorname{PrP}^{C}$ interactors involved in glycolysis include aldolase C (ALDOC) [101] and as well as aldolase A (ALDOA) [99], both catalysing the conversion of fructose-1,6-bisphosphate into glyceraldehyde 3-phosphate (G3P), alpha- and gamma- enolase (ENO1 and ENO2), two isoenzymes that converts 2-phosphoglycerate into phosphoenolpyruvate [97,99], the well-known glyceraldehyde-3phosphate dehydrogenase (GAPDH) [97-99], the triose-phosphate isomerase TPI [98,99] as well as the pyruvate kinases PKM1/PKM2 that catalyse the de-phosphorylation of phosphoenolpyruvate into pyruvate $[97,102]$. $\mathrm{PrPC}^{\mathrm{C}}$ was further shown to interact with both cytoplasmic malate dehydrogenase [97], which converts oxaloacetate into malate, itself being imported in the mitochondrial matrix, and mitochondrial malate dehydrogenase [99], which catalyses the oxidation of malate into oxaloacetate within the Krebs cycle. It is of note that these overall interactions have been recapitulated in several studies, suggesting functional implications. However, apart from $\mathrm{LDH}$, how $\mathrm{PrP}^{\mathrm{C}}$ may influence the activity of these diverse enzymes remains to be explored.

On the other hand, several studies have brought to light links between $\mathrm{PrPC}^{\mathrm{C}}$ and mitochondria. First, beyond its main location at the cell surface, $\operatorname{PrP}^{\mathrm{C}}$ was also found to locate in the mitochondria of healthy mice [103]. $\mathrm{PrPC}^{\mathrm{C}}$ was further shown to co-localise with COX4 [103], one of the nuclear-encoded subunits of complex IV of the respiratory 
chain. In addition, $\mathrm{PrP}^{\mathrm{C}}$-deficient mice were reported to have reduced numbers of mitochondria, which have a larger morphology, and an enhanced maximal respiratory capacity, presumably to compensate for low mitochondrial numbers [104,105]. A proteomic study comparing WT and $\mathrm{PrP}^{\mathrm{C}}$-deficient neurons also exemplified reduced levels of the mitochondrial proteins COX2 in the absence of $\operatorname{PrP}^{\mathrm{C}}$ [106]. Finally, coming back to $\operatorname{PrP}^{\mathrm{C}}$ partners, two independent studies have identified citrate synthase (CS) as a $\operatorname{PrP}^{\mathrm{C}}$ interactor $[97,98]$. Again, whether $\mathrm{PrPC}^{\mathrm{C}}$ modulates the activity of $\mathrm{CS}$ has yet to be investigated.

As a whole, despite the scarcity of data relating to $\mathrm{PrP}^{\mathrm{C}}$ and cancer cell metabolism, the findings obtained with respect to $\mathrm{PrP}^{\mathrm{C}}$ physiological role and, more importantly, to $\operatorname{PrP}^{\mathrm{C}}$ binding partners offer many avenues for future investigation.

\section{Evading Immune Destruction (Emerging Hallmark)}

The second emerging hallmark emphasised by Hanahan and Weinberg refers to the ability of cancer cells to thwart the immune system [14]. A first hint at a link between $\mathrm{PrP}^{\mathrm{C}}$ and immune-evasion can be inferred from the enrichment of PRNP gene expression in the mesenchymal subtype of colorectal cancer [28], itself associated with an immunesuppressive signature [107]. Secondly, a more general role for $\mathrm{PrP}^{\mathrm{C}}$ in immunological quiescence has been proposed, based on its pattern of expression in immune privilege organs as well as its cytoprotective and immune-regulatory function [108]. Mechanistically, $\mathrm{PrP}^{\mathrm{C}}$ may, by itself, induce cell signalling events sustaining immunomodulation, and thereby temper inflammation $[8,108]$. On the other hand, tumour associated $\operatorname{PrP}^{\mathrm{C}}$ controls the levels of several effectors known to promote immune evasion. One such effector is TGF $\beta$, whose soluble levels are regulated by $\operatorname{PrP}^{\mathrm{C}}$ through a yet-to-be-uncovered mechanism [28]. It is indeed now well-acknowledged that TGF $\beta$ inhibits anti-tumour immunity through multiple mechanisms (see [109] for review). Another major player in immune tolerance is IDO (indoleamine 2,2 dioxygenase), an enzyme of the kynurenine pathway [110], which we recently identified as a molecular target downstream from $\operatorname{PrP}^{\mathrm{C}}$ signalling in colorectal cancer [26]. Thus, it appears that $\operatorname{PrP}^{\mathrm{C}}$ from cancer cells orchestrates diverse pathways that altogether tone down the anti-tumour immune response by favouring an immune-suppressive contexture.

\section{Genome Instability and Mutation}

Genomic alterations represent a key characteristic enabling cancer cells to acquire their diverse hallmarks [14]. The question as to whether $\operatorname{PrPC}^{\mathrm{C}}$ may be linked to this enabling characteristic is twofold. First, we may ask whether genome instability and mutation foster the expression of $\operatorname{PrP}^{\mathrm{C}}$. A second question is whether the expression of $\mathrm{PrP}^{\mathrm{C}}$ may afford protection against DNA damage. A major observation regarding the first point is the identification of cell surface $\operatorname{PrP}^{\mathrm{C}}$ as a marker of aneuploidy in a pan-cancer screening study [111]. The authors further reported an increase in $\mathrm{PrPC}^{\mathrm{C}}$ levels in parental or aneuploid HCT116 colorectal cancer cells upon serum-deprivation, which they linked to oxidative stress, and showed that $\operatorname{PrP}^{\mathrm{C}}$ is protective against serum-deprivation-induced necrotic death [111]. On this basis, the authors proposed that the upregulation of $\operatorname{PrP}^{\mathrm{C}}$ in aneuploid cells is a consequence of the oxidative stress associated with this genomic alteration. This notion actually fully fits in with the physiological role described for $\operatorname{PrP}^{\mathrm{C}}$ in the protection against oxidative stress (reviewed in [6]). According to Qin et al. the induction of PRNP gene expression in response to oxidative stress involves the Ataxia Telangiectasia Mutated (ATM) kinase [112]. More recently, ATM was further shown to mediate the upregulation of PRNP transcription in response to irradiation [67]. In line with the Domingues study [111], $\mathrm{PrP}^{\mathrm{C}}$ expression was found to confer a protective role against irradiation [67]. This radioprotective action fits in with the protective role against other types of genotoxic stresses [69], as mentioned above.

Thus, since $\operatorname{Pr} \mathrm{P}^{\mathrm{C}}$ is induced in response to DNA injury and supports protection against DNA damage, we may propose that $\mathrm{PrP}^{\mathrm{C}}$ takes part in the balance between DNA damage and repair, a trade-off for cancer cell survival and growth [113]. 


\section{Tumour-Promoting Inflammation}

Chronic inflammation is a well-acknowledged driver of cancer development [114]. Several pieces of evidence indicate that inflammatory conditions may promote an increase in $\mathrm{PrP}^{\mathrm{C}}$ expression. In the context of cancer, the upregulation of $\mathrm{PrP}^{\mathrm{C}}$ in Merlin-deficient tumours was found to depend on the NFKB transcription factor [24], which embodies a major link between inflammation and cancer (reviewed in [115]). Whether NFKB positively regulates the expression of $\mathrm{PrP}^{\mathrm{C}}$ in other types of tumours obviously deserves further investigation. Conversely, $\mathrm{PrP}^{\mathrm{C}}$ was shown to activate $\mathrm{NF} \kappa \mathrm{B}$-dependent transcription in breast cancer cells [82], or to be necessary for the TNF $\alpha$-dependent activation of NFKB in melanoma M2 cells [116], thereby delineating a bidirectional link between $\mathrm{PrP}^{\mathrm{C}}$ and $\mathrm{NF} \kappa \mathrm{B}$. An alternative yet still hypothetical mechanism leading to an upregulation of $\mathrm{PrP}^{\mathrm{C}}$ would be via ILK, which we showed to be both a downstream target and an upstream regulator of $\operatorname{PrP}^{\mathrm{C}}$ [26] and has been reported to be induced in colonic cells in response to inflammation [117]. Another observation worth noting is the induction of $\operatorname{PrP}^{\mathrm{C}}$ in the mucosa of patients with Helicobacter Pylori gastritis [118], a condition well-known to predispose patients to gastric cancer.

Paradoxically, Prnp-deficient mice were reported to be more sensitive than wildtype mice to dextran sulfate-induced colitis [119]. This is, however, reminiscent of the observations obtained in mice deficient for Yap [120], itself a downstream target of $\operatorname{PrP}^{\mathrm{C}}$ [28]. In the case of Yap, results were interpreted as Yap being necessary for tissue repair after injury, a function whose over-activation supports cancer progression [121]. Likewise, we may surmise that $\mathrm{PrP}^{\mathrm{C}}$ is mandatory for tissue regeneration, in accordance with its function in stem cell self-renewal [11], and that its upregulation under inflammatory conditions contributes to cancer development.

Altogether, the interplay between $\mathrm{PrP}^{\mathrm{C}}$ and tumour-promoting inflammation is currently supported by few studies and could be worthy of further exploration.

\section{Conclusions/Future Prospects}

In summary, we have enlightened the involvement of $\mathrm{PrP}^{\mathrm{C}}$ in cancer biology from the standpoint of the hallmarks of cancer (Figure 5).

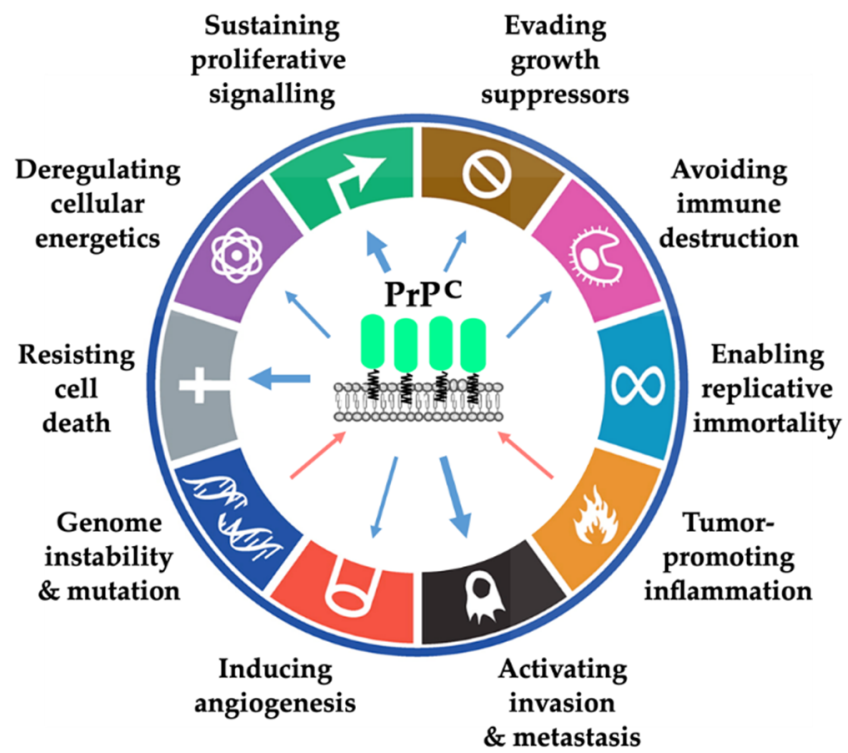

Figure 5. Summary of the data linking $\mathrm{PrP}^{\mathrm{C}}$ with the different hallmarks of cancer. Blue arrows indicate a contribution of $\mathrm{PrP}^{\mathrm{C}}$ to the hallmarks and red arrows indicate a regulation of $\operatorname{PrP}^{\mathrm{C}}$ as a consequence of the hallmark. The thickness of the arrow is related to the amount of evidence supporting the link. The hallmarks of cancer have been adapted from Hanahan and Weinberg [14]. 
While the participation of $\mathrm{PrP}^{\mathrm{C}}$ to some of those hallmarks-most notably proliferation, survival, invasion and metastasis-is substantiated by multiple cell-based, pre-clinical or clinical studies across cancer types, its links to other hallmarks, such as reprogramming of energy metabolism or evading immune destruction, are only beginning to be explored or even merely suggested from observations outside the field of cancer. These underappreciated roles of $\mathrm{PrP}^{\mathrm{C}}$ in cancer-related processes represent important areas for future research. Regarding the binding partners involved in the contribution of $\mathrm{PrP}^{\mathrm{C}}$ to each hallmark (Table 1), data remain scarce at present and are likely to expand in the near future.

Table 1. Summary of the binding partners involved in the $\operatorname{PrP}^{\mathrm{C}}$ contribution to a given hallmark of cancer, in relation with the cancer type.

\begin{tabular}{cccc}
\hline Hallmark & Partner & Cancer Type & Reference \\
\hline Sustaining proliferative signalling & NOTCH1 & Pancreatic & {$[18]$} \\
Sustaining proliferative signalling & STI1 & Glioblastoma & {$[21]$} \\
Resisting cell death & 37LRP & Gastric & {$[62]$} \\
Activating invasion and metastasis & STI1 & Colorectal & {$[87]$} \\
Activating invasion and metastasis & Filamin-A & Melanoma & {$[88]$} \\
\hline
\end{tabular}

Although some of the signalling pathways through which $\operatorname{PrP}^{\mathrm{C}}$ operates have been elucidated (Table 2), the picture is far from complete and also requires further investigation.

Table 2. Summary of the signalling pathways through which $\operatorname{PrPC}^{\mathrm{C}}$ contributes to a given hallmark of cancer, in relation with the cancer type.

\begin{tabular}{|c|c|c|c|}
\hline Hallmark & Partner & Cancer Type & Reference \\
\hline Sustaining proliferative signalling & PI3K/AKT- CyclinD1 & Gastric & [15] \\
\hline Sustaining proliferative signalling & NOTCH1 & Pancreatic & [18] \\
\hline Sustaining proliferative signalling & ILK & Colorectal & [26] \\
\hline Evading growth suppressors & NF2 & Schwannoma & [24] \\
\hline Evading growth suppressors & TGF $\beta$ & Colorectal & [26] \\
\hline Resisting cell death & MDR1 & Gastric & [54] \\
\hline Resisting cell death & $\mathrm{PI} 3 \mathrm{~K} / \mathrm{AKT}$ & Gastric & [59] \\
\hline Resisting cell death & BCL2 & Gastric & {$[42,54,58]$} \\
\hline Resisting cell death & BCL2 & Breast & [51] \\
\hline Resisting cell death & BCL2 & Glioma & [63] \\
\hline Resisting cell death & $\begin{array}{c}\text { Survivin/cIAP- } \\
1 / \text { XIAP }\end{array}$ & Colorectal & [25] \\
\hline Resisting cell death & Par4 & Glioblastoma & [23] \\
\hline Resisting cell death & Soluble $\operatorname{Pr} \mathrm{P}^{\mathrm{C}}$ & Breast & {$[66]$} \\
\hline Inducing angiogenesis & Hypoxia & Colorectal & [31] \\
\hline Activating invasion and metastasis & MMPs & Breast & {$[52,82]$} \\
\hline Activating invasion and metastasis & MMPs & Gastric & [83] \\
\hline Activating invasion and metastasis & NOTCH1 & Pancreatic & [18] \\
\hline Activating invasion and metastasis & JNK & Lung & [84] \\
\hline Reprogramming of energy metabolism & GLUT1 & Colorectal & [29] \\
\hline Evading immune surveillance & TGF $\beta$ & Colorectal & [26] \\
\hline Evading immune surveillance & IDO & Colorectal & [26] \\
\hline
\end{tabular}

Casting further light on these specific points will undoubtedly help reach an integrated view of the multifaceted contribution of $\mathrm{PrP}^{\mathrm{C}}$ to cancer initiation, promotion and progression.

Author Contributions: S.M.-R. wrote the review. A.G. prepared the figures. P.L.-P. reviewed and edited the draft. All authors have read and agreed to the published version of the manuscript. 
Funding: Institut National de la Santé et de la Recherche Médicale; Association pour la Recherche sur le Cancer (grant number PJA 20171206220); Cancéropôle Ile de France (grant number 2016-1EMERG-36-UP 5-1); SIRIC CARPEM (Cancer Research for Personalized Medicine, INCa-DGOS Inserm_12561).

Acknowledgments: The authors wish to thank Fatima Djouadi for her critical reading of the review. We are grateful to D. Le Corre who produced some of the results summarised in the present review. We apologise to those whose work has not been cited owing to space limitations.

Conflicts of Interest: The authors declare no conflict of interest in the context of the present review.

$\begin{array}{ll}\text { Abbreviations } & \\ \text { 5-FU } & \text { 5-fluorouracil } \\ \text { APE1 } & \begin{array}{l}\text { apurinic/apyrimidinic endonuclease 1 } \\ \text { ataxia telangiectasia mutated } \\ \text { epithelial to mesenchymal transition } \\ \text { ATM }\end{array} \\ \text { EMT } & \text { glycosyl-phosphatidylinositol } \\ \text { EGFR } & \text { hypoxia-inducible factor 1 alpha } \\ \text { GPI } & \text { heat shock protein 70 member 1-like } \\ \text { HIF-1 } \alpha & \text { human umbilical vein endothelial cell } \\ \text { HSPA1L } & \text { integrin linked kinase } \\ \text { HUVEC } & \text { neurofibromatosis type 2 } \\ \text { ILK } & \text { platelet-derived growth factor C } \\ \text { NF2 } & \text { cellular prion protein } \\ \text { PDGFC } & \text { scrapie prion protein } \\ \text { PrPC } & \text { 5-FU resistant SNU-C5 cells } \\ \text { PrPSc } & \text { transforming growth factor } \beta \\ \text { SNU-C5/FUR } & \text { tumour necrosis factor- } \alpha\end{array}$

\section{References}

1. Oesch, B.; Westaway, D.; Walchli, M.; McKinley, M.P.; Kent, S.B.; Aebersold, R.; Barry, R.A.; Tempst, P.; Teplow, D.B.; Hood, L.E.; et al. A Cellular Gene Encodes Scrapie PrP 27-30 Protein. Cell 1985, 40, 735-746. [CrossRef]

2. Aguzzi, A.; Baumann, F.; Bremer, J. The Prion's Elusive Reason for Being. Annu. Rev. Neurosci. 2008, 31, 439-477. [CrossRef] [PubMed]

3. Sarnataro, D.; Pepe, A.; Zurzolo, C. Chapter Three-Cell Biology of Prion Protein. In Progress in Molecular Biology and Translational Science; Legname, G., Vanni, S., Eds.; Prion Protein; Academic Press: Cambridge, MA, USA, 2017; Volume 150, pp. 57-82.

4. Evans, E.G.B.; Millhauser, G.L. Copper- and Zinc-Promoted Interdomain Structure in the Prion Protein: A Mechanism for Autoinhibition of the Neurotoxic N-Terminus. Prog. Mol. Biol. Transl. Sci. 2017, 150, 35-56. [CrossRef] [PubMed]

5. Linsenmeier, L.; Altmeppen, H.C.; Wetzel, S.; Mohammadi, B.; Saftig, P.; Glatzel, M. Diverse Functions of the Prion Protein-Does Proteolytic Processing Hold the Key? Biochim. Biophys. Acta Mol. Cell Res. 2017, 1864, 2128-2137. [CrossRef]

6. Hirsch, T.Z.; Martin-Lannerée, S.; Mouillet-Richard, S. Functions of the Prion Protein. Prog. Mol. Biol. Transl. Sci. 2017, 150, 1-34. [CrossRef]

7. Hirsch, T.Z.; Hernandez-Rapp, J.; Martin-Lanneree, S.; Launay, J.M.; Mouillet-Richard, S. PrPC Signalling in Neurons: From Basics to Clinical Challenges. Biochimie 2014, 104C, 2-11. [CrossRef]

8. Manni, G.; Lewis, V.; Senesi, M.; Spagnolli, G.; Fallarino, F.; Collins, S.J.; Mouillet-Richard, S.; Biasini, E. The Cellular Prion Protein beyond Prion Diseases. Swiss Med. Wkly. 2020, 150, w20222. [CrossRef] [PubMed]

9. Corsaro, A.; Bajetto, A.; Thellung, S.; Begani, G.; Villa, V.; Nizzari, M.; Pattarozzi, A.; Solari, A.; Gatti, M.; Pagano, A.; et al. Cellular Prion Protein Controls Stem Cell-like Properties of Human Glioblastoma Tumor-Initiating Cells. Oncotarget 2016, 7, 38638. [CrossRef]

10. Go, G.; Lee, S.H. The Cellular Prion Protein: A Promising Therapeutic Target for Cancer. Int. J. Mol. Sci. 2020, 21, 9208. [CrossRef]

11. Martin-Lannerée, S.; Hirsch, T.Z.; Hernandez-Rapp, J.; Halliez, S.; Vilotte, J.L.; Launay, J.M.; Mouillet-Richard, S. PrPC from Stem Cells to Cancer. Front. Cell Dev. Biol. 2014, 2, 55. [PubMed]

12. Ryskalin, L.; Biagioni, F.; Busceti, C.L.; Giambelluca, M.A.; Morelli, L.; Frati, A.; Fornai, F. The Role of Cellular Prion Protein in Promoting Stemness and Differentiation in Cancer. Cancers 2021, 13, 170. [CrossRef] [PubMed]

13. Hanahan, D.; Weinberg, R.A. The Hallmarks of Cancer. Cell 2000, 100, 57-70. [CrossRef]

14. Hanahan, D.; Weinberg, R.A. Hallmarks of Cancer: The next Generation. Cell 2011, 144, 646-674. [CrossRef] 
15. Liang, J.; Pan, Y.; Zhang, D.; Guo, C.; Shi, Y.; Wang, J.; Chen, Y.; Wang, X.; Liu, J.; Guo, X.; et al. Cellular Prion Protein Promotes Proliferation and G1/S Transition of Human Gastric Cancer Cells SGC7901 and AGS. FASEB J. 2007, 21, 2247-2256. [CrossRef]

16. Vassallo, N.; Herms, J.; Behrens, C.; Krebs, B.; Saeki, K.; Onodera, T.; Windl, O.; Kretzschmar, H.A. Activation of Phosphatidylinositol 3-Kinase by Cellular Prion Protein and Its Role in Cell Survival. Biochem. Biophys. Res. Commun. 2005, 332, 75-82. [CrossRef] [PubMed]

17. Li, C.; Yu, S.; Nakamura, F.; Yin, S.; Xu, J.; Petrolla, A.A.; Singh, N.; Tartakoff, A.; Abbott, D.W.; Xin, W.; et al. Binding of Pro-Prion to Filamin a Disrupts Cytoskeleton and Correlates with Poor Prognosis in Pancreatic Cancer. J. Clin. Invest. 2009, 119, $2725-2736$. [CrossRef] [PubMed]

18. Wang, Y.; Yu, S.; Huang, D.; Cui, M.; Hu, H.; Zhang, L.; Wang, W.; Parameswaran, N.; Jackson, M.; Osborne, B.; et al. Cellular Prion Protein Mediates Pancreatic Cancer Cell Survival and Invasion through Association with and Enhanced Signaling of Notch1. Am. J. Pathol. 2016, 186, 2945-2956. [CrossRef] [PubMed]

19. Li, L.T.; Jiang, G.; Chen, Q.; Zheng, J.N. Ki67 Is a Promising Molecular Target in the Diagnosis of Cancer (Review). Mol. Med. Rep. 2015, 11, 1566-1572. [CrossRef]

20. Martin-Lannerée, S.; Halliez, S.; Hirsch, T.Z.; Hernandez-Rapp, J.; Passet, B.; Tomkiewicz, C.; Villa-Diaz, A.; Torres, J.-M.; Launay, J.-M.; Béringue, V.; et al. The Cellular Prion Protein Controls Notch Signaling in Neural Stem/Progenitor Cells. Stem Cells 2017, 35, 754-765. [CrossRef] [PubMed]

21. Lopes, M.H.; Santos, T.G.; Rodrigues, B.R.; Queiroz-Hazarbassanov, N.; Cunha, I.W.; Wasilewska-Sampaio, A.P.; Costa-Silva, B.; Marchi, F.A.; Bleggi-Torres, L.F.; Sanematsu, P.I.; et al. Disruption of Prion Protein-HOP Engagement Impairs Glioblastoma Growth and Cognitive Decline and Improves Overall Survival. Oncogene 2014, 34, 3305-3314. [CrossRef]

22. Iglesia, R.P.; Prado, M.B.; Cruz, L.; Martins, V.R.; Santos, T.G.; Lopes, M.H. Engagement of Cellular Prion Protein with the Co-Chaperone Hsp70/90 Organizing Protein Regulates the Proliferation of Glioblastoma Stem-like Cells. Stem Cell Res. Ther. 2017, 8, 76. [CrossRef]

23. Zhuang, D.; Liu, Y.; Mao, Y.; Gao, L.; Zhang, H.; Luan, S.; Huang, F.; Li, Q. TMZ-Induced PrPc/Par-4 Interaction Promotes the Survival of Human Glioma Cells. Int. J. Cancer 2012, 130, 309-318. [CrossRef] [PubMed]

24. Provenzano, L.; Ryan, Y.; Hilton, D.A.; Lyons-Rimmer, J.; Dave, F.; Maze, E.A.; Adams, C.L.; Rigby-Jones, R.; Ammoun, S.; Hanemann, C.O. Cellular Prion Protein (PrPC) in the Development of Merlin-Deficient Tumours. Oncogene 2017, 36, 6132-6142. [CrossRef] [PubMed]

25. Chieng, C.K.-L.; Say, Y.-H. Cellular Prion Protein Contributes to LS 174T Colon Cancer Cell Carcinogenesis by Increasing Invasiveness and Resistance against Doxorubicin-Induced Apoptosis. Tumour Biol. 2015, 36, 8107-8120. [CrossRef] [PubMed]

26. Ghazi, A.; Le Corre, D.; Pilati, C.; Taieb, J.; Aparicio, T.; Didelot, A.; Dedhar, S.; Mulot, C.; Le Malicot, K.; Djouadi, F.; et al. Prognostic Value of the PrPC-ILK-IDO1 Axis in the Mesenchymal Colorectal Cancer Subtype. Oncoimmunology 2021, 10, 1940674. [CrossRef]

27. Go, G.; Yun, C.W.; Yoon, Y.M.; Lim, J.H.; Lee, J.H.; Lee, S.H. Role of PrPC in Cancer Stem Cell Characteristics and Drug Resistance in Colon Cancer Cells. Anticancer Res. 2020, 40, 5611-5620. [CrossRef]

28. Le Corre, D.; Ghazi, A.; Balogoun, R.; Pilati, C.; Aparicio, T.; Martin-Lannerée, S.; Marisa, L.; Djouadi, F.; Poindessous, V.; Crozet, C.; et al. The Cellular Prion Protein Controls the Mesenchymal-like Molecular Subtype and Predicts Disease Outcome in Colorectal Cancer. EBioMedicine 2019, 46, 94-104. [CrossRef]

29. Li, Q.Q.; Sun, Y.P.; Ruan, C.P.; Xu, X.Y.; Ge, J.H.; He, J.; Xu, Z.D.; Wang, Q.; Gao, W.C. Cellular Prion Protein Promotes Glucose Uptake through the Fyn-HIF-2 $\alpha$-Glut1 Pathway to Support Colorectal Cancer Cell Survival. Cancer Sci. 2011, 102, 400-406. [CrossRef]

30. Yap, Y.H.-Y.; Say, Y.-H. Resistance against Tumour Necrosis Factor $\alpha$ Apoptosis by the Cellular Prion Protein Is Cell-Specific for Oral, Colon and Kidney Cancer Cell Lines. Cell Biol. Int. 2012, 36, 273-277. [CrossRef]

31. Yun, C.-W.; Lee, J.-H.; Go, G.; Jeon, J.; Yoon, S.; Lee, S.-H. Prion Protein of Extracellular Vesicle Regulates the Progression of Colorectal Cancer. Cancers 2021, 13, 2144. [CrossRef]

32. Dias, M.V.S.; Teixeira, B.L.; Rodrigues, B.R.; Sinigaglia-Coimbra, R.; Porto-Carreiro, I.; Roffé, M.; Hajj, G.N.M.; Martins, V.R. PRNP/Prion Protein Regulates the Secretion of Exosomes Modulating CAV1/Caveolin-1-Suppressed Autophagy. Autophagy 2016, 12, 2113-2128. [CrossRef]

33. Llorens, F.; Carulla, P.; Villa, A.; Torres, J.M.; Fortes, P.; Ferrer, I.; del Rio, J.A. PrP(C) Regulates Epidermal Growth Factor Receptor Function and Cell Shape Dynamics in Neuro2a Cells. J. Neurochem. 2013, 127, 124-138. [CrossRef]

34. Atkinson, C.J.; Kawamata, F.; Liu, C.; Ham, S.; Győrffy, B.; Munn, A.L.; Wei, M.Q.; Möller, A.; Whitehall, V.; Wiegmans, A.P. EGFR and Prion Protein Promote Signaling via FOXO3a-KLF5 Resulting in Clinical Resistance to Platinum Agents in Colorectal Cancer. Mol. Oncol. 2019, 13, 725-737. [CrossRef]

35. Checler, F.; Alves da Costa, C. P53 in Neurodegenerative Diseases and Brain Cancers. Pharmacol. Ther. 2014, 142, 99-113. [CrossRef]

36. Paitel, E.; Fahraeus, R.; Checler, F. Cellular Prion Protein Sensitizes Neurons to Apoptotic Stimuli through Mdm2-Regulated and P53-Dependent Caspase 3-like Activation. J. Biol. Chem. 2003, 278, 10061-10066. [CrossRef]

37. Sunyach, C.; Cisse, M.A.; da Costa, C.A.; Vincent, B.; Checler, F. The C-Terminal Products of Cellular Prion Protein Processing, C1 and C2, Exert Distinct Influence on P53-Dependent Staurosporine-Induced Caspase-3 Activation. J. Biol. Chem. 2007, 282, 1956-1963. [CrossRef] 
38. Guillot-Sestier, M.V.; Sunyach, C.; Druon, C.; Scarzello, S.; Checler, F. The $\alpha$-Secretase-Derived N-Terminal Product of Cellular Prion, N1, Displays Neuroprotective Function In Vitro and In Vivo. J. Biol. Chem. 2009, 284, 35973-35986. [CrossRef] [PubMed]

39. Altmeppen, H.C.; Prox, J.; Puig, B.; Kluth, M.A.; Bernreuther, C.; Thurm, D.; Jorissen, E.; Petrowitz, B.; Bartsch, U.; De Strooper, B.; et al. Lack of A-Disintegrin-and-Metalloproteinase ADAM10 Leads to Intracellular Accumulation and Loss of Shedding of the Cellular Prion Protein In Vivo. Mol. Neurodegener. 2011, 6, 36. [CrossRef]

40. Weiss, E.; Ramljak, S.; Asif, A.R.; Ciesielczyk, B.; Schmitz, M.; Gawinecka, J.; Schulz-Schaeffer, W.; Behrens, C.; Zerr, I. Cellular Prion Protein Overexpression Disturbs Cellular Homeostasis in SH-SY5Y Neuroblastoma Cells but Does Not Alter P53 Expression: A Proteomic Study. Neuroscience 2010, 169, 1640-1650. [CrossRef] [PubMed]

41. Liang, J.; Parchaliuk, D.; Medina, S.; Sorensen, G.; Landry, L.; Huang, S.; Wang, M.; Kong, Q.; Booth, S.A. Activation of P53-Regulated pro-Apoptotic Signaling Pathways in PrP-Mediated Myopathy. BMC Genomics 2009, 10, 201. [CrossRef] [PubMed]

42. Liang, J.; Pan, Y.L.; Ning, X.X.; Sun, L.J.; Lan, M.; Hong, L.; Du, J.P.; Liu, N.; Liu, C.J.; Qiao, T.D.; et al. Overexpression of PrPC and Its Antiapoptosis Function in Gastric Cancer. Tumour Biol. 2006, 27, 84-91. [CrossRef]

43. Curto, M.; McClatchey, A.I. Nf2/Merlin: A Coordinator of Receptor Signalling and Intercellular Contact. Br. J. Cancer 2008, 98, 256-262. [CrossRef]

44. Serrano, I.; McDonald, P.C.; Lock, F.; Muller, W.J.; Dedhar, S. Inactivation of the Hippo Tumour Suppressor Pathway by Integrin-Linked Kinase. Nat. Commun. 2013, 4, 2976. [CrossRef]

45. Mouillet-Richard, S.; Laurent-Puig, P. YAP/TAZ Signalling in Colorectal Cancer: Lessons from Consensus Molecular Subtypes. Cancers 2020, 12, 3160. [CrossRef] [PubMed]

46. Zhao, B.; Tumaneng, K.; Guan, K.-L. The Hippo Pathway in Organ Size Control, Tissue Regeneration and Stem Cell Self-Renewal. Nat. Cell Biol. 2011, 13, 877-883. [CrossRef] [PubMed]

47. Tauriello, D.V.F.; Batlle, E. Targeting the Microenvironment in Advanced Colorectal Cancer. Trends Cancer 2016, 2, 495-504. [CrossRef] [PubMed]

48. Batlle, E.; Massagué, J. Transforming Growth Factor- $\beta$ Signaling in Immunity and Cancer. Immunity 2019, 50, 924-940. [CrossRef] [PubMed]

49. Zhao, Y.; You, H.; Liu, F.; An, H.; Shi, Y.; Yu, Q.; Fan, D. Differentially Expressed Gene Profiles between Multidrug Resistant Gastric Adenocarcinoma Cells and Their Parental Cells. Cancer Lett. 2002, 185, 211-218. [CrossRef]

50. Diarra-Mehrpour, M.; Arrabal, S.; Jalil, A.; Pinson, X.; Gaudin, C.; Pietu, G.; Pitaval, A.; Ripoche, H.; Eloit, M.; Dormont, D.; et al. Prion Protein Prevents Human Breast Carcinoma Cell Line from Tumor Necrosis Factor $\alpha$-Induced Cell Death. Cancer Res. 2004, 64, 719-727. [CrossRef]

51. Meslin, F.; Hamai, A.; Gao, P.; Jalil, A.; Cahuzac, N.; Chouaib, S.; Mehrpour, M. Silencing of Prion Protein Sensitizes Breast Adriamycin-Resistant Carcinoma Cells to TRAIL-Mediated Cell Death. Cancer Res. 2007, 67, 10910-10919. [CrossRef]

52. Cheng, Y.; Tao, L.; Xu, J.; Li, Q.; Yu, J.; Jin, Y.; Chen, Q.; Xu, Z.; Zou, Q.; Liu, X. CD44/Cellular Prion Protein Interact in Multidrug Resistant Breast Cancer Cells and Correlate with Responses to Neoadjuvant Chemotherapy in Breast Cancer Patients. Mol. Carcinog. 2013, 53, 686-697. [CrossRef]

53. Lee, J.H.; Yun, C.W.; Lee, S.H. Cellular Prion Protein Enhances Drug Resistance of Colorectal Cancer Cells via Regulation of a Survival Signal Pathway. Biomol. Ther. 2018, 26, 313-321. [CrossRef]

54. Du, J.; Pan, Y.; Shi, Y.; Guo, C.; Jin, X.; Sun, L.; Liu, N.; Qiao, T.; Fan, D. Overexpression and Significance of Prion Protein in Gastric Cancer and Multidrug-Resistant Gastric Carcinoma Cell Line SGC7901/ADR. Int. J. Cancer 2005, 113, 213-220. [CrossRef]

55. Liang, J.; Bai, F.; Luo, G.; Wang, J.; Liu, J.; Ge, F.; Pan, Y.; Yao, L.; Du, R.; Li, X.; et al. Hypoxia Induced Overexpression of PrP(C) in Gastric Cancer Cell Lines. Cancer Biol. Ther. 2007, 6, 769-774. [CrossRef] [PubMed]

56. Lee, J.H.; Han, Y.-S.; Yoon, Y.M.; Yun, C.W.; Yun, S.P.; Kim, S.M.; Kwon, H.Y.; Jeong, D.; Baek, M.J.; Lee, H.J.; et al. Role of HSPA1L as a Cellular Prion Protein Stabilizer in Tumor Progression via HIF-1 $\alpha /$ GP78 Axis. Oncogene 2017, 36, 6555-6567. [CrossRef]

57. Park, J.-Y.; Jeong, J.-K.; Lee, J.-H.; Moon, J.-H.; Kim, S.-W.; Lee, Y.-J.; Park, S.-Y. Induction of Cellular Prion Protein (PrPc) under Hypoxia Inhibits Apoptosis Caused by TRAIL Treatment. Oncotarget 2015, 6, 5342-5353. [CrossRef] [PubMed]

58. Wang, J.-H.; Du, J.-P.; Zhang, Y.-H.; Zhao, X.-J.; Fan, R.-Y.; Wang, Z.-H.; Wu, Z.-T.; Han, Y. Dynamic Changes and Surveillance Function of Prion Protein Expression in Gastric Cancer Drug Resistance. World J. Gastroenterol. 2011, 17, 3986-3993. [CrossRef] [PubMed]

59. Liang, J.; Ge, F.; Guo, C.; Luo, G.; Wang, X.; Han, G.; Zhang, D.; Wang, J.; Li, K.; Pan, Y.; et al. Inhibition of PI3K/Akt Partially Leads to the Inhibition of $\operatorname{PrP}(\mathrm{C})$-Induced Drug Resistance in Gastric Cancer Cells. FEBS J. 2009, 276, 685-694. [CrossRef]

60. Wang, J.H.; Du, J.P.; Li, S.J.; Zhai, L.P.; Yang, X.Y.; Wang, Z.H.; Wu, Z.T.; Han, Y. Octarepeat Peptides of Prion Are Essential for Multidrug Resistance in Gastric Cancer Cells. J. Dig. Dis. 2012, 13, 143-152. [CrossRef]

61. Liang, J.; Wang, J.; Luo, G.; Pan, Y.; Wang, X.; Guo, C.; Zhang, D.; Yin, F.; Zhang, X.; Liu, J.; et al. Function of PrPC (1-OPRD) in Biological Activities of Gastric Cancer Cell Lines. J. Cell. Mol. Med. 2009, 13, 4453-4464. [CrossRef]

62. Luo, G.; Wang, W.; Wu, Q.; Lu, Y.; Su, T.; Gu, N.; Li, K.; Wang, J.; Du, R.; Zhao, X.; et al. MGr1-Antigen/37 KDa Laminin Receptor Precursor Promotes Cellular Prion Protein Induced Multi-Drug-Resistance of Gastric Cancer. Oncotarget 2017, 8, 71630-71641. [CrossRef]

63. Barbieri, G.; Palumbo, S.; Gabrusiewicz, K.; Azzalin, A.; Marchesi, N.; Spedito, A.; Biggiogera, M.; Sbalchiero, E.; Mazzini, G.; Miracco, C.; et al. Silencing of Cellular Prion Protein (PrPC) Expression by DNA-Antisense Oligonucleotides Induces AutophagyDependent Cell Death in Glioma Cells. Autophagy 2011, 7, 840-853. [CrossRef] 
64. Roucou, X.; Gains, M.; LeBlanc, A.C. Neuroprotective Functions of Prion Protein. J. Neurosci. Res. 2004, 75, 153-161. [CrossRef] [PubMed]

65. Arora, A.S.; Zafar, S.; Latif, U.; Llorens, F.; Sabine, M.; Kumar, P.; Tahir, W.; Thüne, K.; Shafiq, M.; Schmitz, M.; et al. The Role of Cellular Prion Protein in Lipid Metabolism in the Liver. Prion 2020, 14, 95-108. [CrossRef]

66. Wiegmans, A.P.; Saunus, J.M.; Ham, S.; Lobb, R.; Kutasovic, J.R.; Dalley, A.J.; Miranda, M.; Atkinson, C.; Foliaki, S.T.; Ferguson, K.; et al. Secreted Cellular Prion Protein Binds Doxorubicin and Correlates with Anthracycline Resistance in Breast Cancer. JCI Insight 2019, 5, e124092. [CrossRef] [PubMed]

67. Bernardino-Sgherri, J.; Siberchicot, C.; Auvré, F.; Busso, D.; Brocas, C.; El Masri, G.; Lioutsko, A.; Ferri, F.; Radicella, J.P.; Romeo, P.-H.; et al. Tumor Resistance to Radiotherapy Is Triggered by an ATM/TAK1-Dependent-Increased Expression of the Cellular Prion Protein. Oncogene 2021, 40, 3460-3469. [CrossRef] [PubMed]

68. Siberchicot, C.; Gault, N.; Déchamps, N.; Barroca, V.; Aguzzi, A.; Roméo, P.-H.; Radicella, J.P.; Bravard, A.; Bernardino-Sgherri, J. Prion Protein Deficiency Impairs Hematopoietic Stem Cell Determination and Sensitizes Myeloid Progenitors to Irradiation. Haematologica 2020, 105, 1216-1222. [CrossRef]

69. Bravard, A.; Auvré, F.; Fantini, D.; Bernardino-Sgherri, J.; Sissoëff, L.; Daynac, M.; Xu, Z.; Etienne, O.; Dehen, C.; Comoy, E.; et al. The Prion Protein Is Critical for DNA Repair and Cell Survival after Genotoxic Stress. Nucleic Acids Res. 2015, 43, 904-916. [CrossRef]

70. Turu, M.; Slevin, M.; Ethirajan, P.; Luque, A.; Elasbali, A.; Font, A.; Gaffney, J.; Cairols, M.; Kumar, P.; Kumar, S.; et al. The Normal Cellular Prion Protein and Its Possible Role in Angiogenesis. Front. Biosci. J. Virtual Libr. 2008, 13, 6491-6500. [CrossRef]

71. Doeppner, T.R.; Kaltwasser, B.; Schlechter, J.; Jaschke, J.; Kilic, E.; Bähr, M.; Hermann, D.M.; Weise, J. Cellular Prion Protein Promotes Post-Ischemic Neuronal Survival, Angioneurogenesis and Enhances Neural Progenitor Cell Homing via Proteasome Inhibition. Cell Death Dis. 2015, 6, e2024. [CrossRef]

72. Alfaidy, N.; Chauvet, S.; Andrei, S.; Salomon, A.; Saoudi, Y.; Richaud, P.; Aude-Garcia, C.; Hoffmann, P.; Andrieux, A.; Moulis, J.M.; et al. Prion Protein Expression and Functional Importance in Developmental Angiogenesis: Role in Oxidative Stress and Copper Homeostasis. Antioxid. Redox Signal. 2012, 18, 400-411. [CrossRef] [PubMed]

73. Ramljak, S.; Herlyn, H.; Zerr, I. Cellular Prion Protein (PrPc) and Hypoxia: True to Each Other in Good Times and in Bad, in Sickness, and in Health. Front. Cell. Neurosci. 2016, 10, 292. [CrossRef]

74. Singleton, D.C.; Macann, A.; Wilson, W.R. Therapeutic Targeting of the Hypoxic Tumour Microenvironment. Nat. Rev. Clin. Oncol. 2021. [CrossRef]

75. Möller, A.; Lobb, R.J. The Evolving Translational Potential of Small Extracellular Vesicles in Cancer. Nat. Rev. Cancer 2020, 20, 697-709. [CrossRef]

76. Cao, R.; Bråkenhielm, E.; Li, X.; Pietras, K.; Widenfalk, J.; Ostman, A.; Eriksson, U.; Cao, Y. Angiogenesis Stimulated by PDGF-CC, a Novel Member in the PDGF Family, Involves Activation of PDGFR- $\alpha \alpha$ and- $\alpha \beta$ Receptors. FASEB J. 2002, 16, $1575-1583$. [CrossRef]

77. Azad, T.; Ghahremani, M.; Yang, X. The Role of YAP and TAZ in Angiogenesis and Vascular Mimicry. Cells 2019, 8, 407. [CrossRef]

78. Chen, Z.; Morales, J.E.; Avci, N.; Guerrero, P.A.; Rao, G.; Seo, J.H.; McCarty, J.H. The Vascular Endothelial Cell-Expressed Prion Protein Doppel Promotes Angiogenesis and Blood-Brain Barrier Development. Development 2020, 147, dev193094. [CrossRef]

79. Al-Hilal, T.A.; Chung, S.W.; Choi, J.U.; Alam, F.; Park, J.; Kim, S.W.; Kim, S.Y.; Ahsan, F.; Kim, I.-S.; Byun, Y. Targeting Prion-like Protein Doppel Selectively Suppresses Tumor Angiogenesis. J. Clin. Invest. 2016, 126, 1251-1266. [CrossRef]

80. Ciric, D.; Rezaei, H. Biochemical Insight into the Prion Protein Family. Front. Cell Dev. Biol. 2015, 3, 5. [CrossRef] [PubMed]

81. Lu, W.; Kang, Y. Epithelial-Mesenchymal Plasticity in Cancer Progression and Metastasis. Dev. Cell 2019, 49, 361-374. [CrossRef] [PubMed]

82. Gil, M.; Kim, Y.K.; Kim, K.-E.; Kim, W.; Park, C.-S.; Lee, K.J. Cellular Prion Protein Regulates Invasion and Migration of Breast Cancer Cells through MMP-9 Activity. Biochem. Biophys. Res. Commun. 2016, 470, 213-219. [CrossRef]

83. Pan, Y.; Zhao, L.; Liang, J.; Liu, J.; Shi, Y.; Liu, N.; Zhang, G.; Jin, H.; Gao, J.; Xie, H.; et al. Cellular Prion Protein Promotes Invasion and Metastasis of Gastric Cancer. FASEB J. 2006, 20, 1886-1888. [CrossRef] [PubMed]

84. Lin, S.-C.; Lin, C.-H.; Shih, N.-C.; Liu, H.-L.; Wang, W.-C.; Lin, K.-Y.; Liu, Z.-Y.; Tseng, Y.-J.; Chang, H.-K.; Lin, Y.-C.; et al. Cellular Prion Protein Transcriptionally Regulated by NFIL3 Enhances Lung Cancer Cell Lamellipodium Formation and Migration through JNK Signaling. Oncogene 2020, 39, 385-398. [CrossRef] [PubMed]

85. Wang, Q.; Qian, J.; Wang, F.; Ma, Z. Cellular Prion Protein Accelerates Colorectal Cancer Metastasis via the Fyn-SP1-SATB1 Axis. Oncol. Rep. 2012, 28, 2029-2034. [CrossRef] [PubMed]

86. Du, L.; Rao, G.; Wang, H.; Li, B.; Tian, W.; Cui, J.; He, L.; Laffin, B.; Tian, X.; Hao, C.; et al. CD44-Positive Cancer Stem Cells Expressing Cellular Prion Protein Contribute to Metastatic Capacity in Colorectal Cancer. Cancer Res. 2013, 73, $2682-2694$. [CrossRef]

87. De Lacerda, T.C.S.; Costa-Silva, B.; Giudice, F.S.; Dias, M.V.S.; de Oliveira, G.P.; Teixeira, B.L.; Dos Santos, T.G.; Martins, V.R. Prion Protein Binding to HOP Modulates the Migration and Invasion of Colorectal Cancer Cells. Clin. Exp. Metastasis 2016, 33, 441-451. [CrossRef]

88. Li, C.; Yu, S.; Nakamura, F.; Pentikäinen, O.T.; Singh, N.; Yin, S.; Xin, W.; Sy, M.-S. Pro-Prion Binds Filamin A, Facilitating Its Interaction with Integrin $\beta 1$, and Contributes to Melanomagenesis. J. Biol. Chem. 2010, 285, 30328-30339. [CrossRef] 
89. Dery, M.A.; Jodoin, J.; Ursini-Siegel, J.; Aleynikova, O.; Ferrario, C.; Hassan, S.; Basik, M.; Leblanc, A.C. Endoplasmic Reticulum Stress Induces PRNP Prion Protein Gene Expression in Breast Cancer. Breast Cancer Res. 2013, 15, R22. [CrossRef]

90. Zhou, L.; Shang, Y.; Liu, C.; Li, J.; Hu, H.; Liang, C.; Han, Y.; Zhang, W.; Liang, J.; Wu, K. Overexpression of PrPc, Combined with MGr1-Ag/37LRP, Is Predictive of Poor Prognosis in Gastric Cancer. Int. J. Cancer 2014, 135, 2329-2337. [CrossRef]

91. Coebergh van den Braak, R.R.J.; Ten Hoorn, S.; Sieuwerts, A.M.; Tuynman, J.B.; Smid, M.; Wilting, S.M.; Martens, J.W.M.; Punt, C.J.A.; Foekens, J.A.; Medema, J.P.; et al. Interconnectivity between Molecular Subtypes and Tumor Stage in Colorectal Cancer. BMC Cancer 2020, 20, 850. [CrossRef]

92. Faubert, B.; Solmonson, A.; DeBerardinis, R.J. Metabolic Reprogramming and Cancer Progression. Science 2020, 368 , eaaw5473. [CrossRef] [PubMed]

93. De Wit, M.; Jimenez, C.R.; Carvalho, B.; Belien, J.A.M.; Delis-van Diemen, P.M.; Mongera, S.; Piersma, S.R.; Vikas, M.; Navani, S.; Pontén, F; et al. Cell Surface Proteomics Identifies Glucose Transporter Type 1 and Prion Protein as Candidate Biomarkers for Colorectal Adenoma-to-Carcinoma Progression. Gut 2012, 61, 855-864. [CrossRef] [PubMed]

94. Ashok, A.; Singh, N. Prion Protein Modulates Glucose Homeostasis by Altering Intracellular Iron. Sci. Rep. 2018, 8, 6556. [CrossRef] [PubMed]

95. Ramljak, S.; Schmitz, M.; Repond, C.; Zerr, I.; Pellerin, L. Altered MRNA and Protein Expression of Monocarboxylate Transporter MCT1 in the Cerebral Cortex and Cerebellum of Prion Protein Knockout Mice. Int. J. Mol. Sci. 2021, 22, 1566. [CrossRef] [PubMed]

96. Kleene, R.; Loers, G.; Langer, J.; Frobert, Y.; Buck, F.; Schachner, M. Prion Protein Regulates Glutamate-Dependent Lactate Transport of Astrocytes. J. Neurosci. Off. J. Soc. Neurosci. 2007, 27, 12331-12340. [CrossRef] [PubMed]

97. Rutishauser, D.; Mertz, K.D.; Moos, R.; Brunner, E.; Rulicke, T.; Calella, A.M.; Aguzzi, A. The Comprehensive Native Interactome of a Fully Functional Tagged Prion Protein. PLoS ONE 2009, 4, e4446. [CrossRef] [PubMed]

98. Watts, J.C.; Huo, H.; Bai, Y.; Ehsani, S.; Jeon, A.H.; Shi, T.; Daude, N.; Lau, A.; Young, R.; Xu, L.; et al. Interactome Analyses Identify Ties of PrP and Its Mammalian Paralogs to Oligomannosidic N-Glycans and Endoplasmic Reticulum-Derived Chaperones. PLoS Pathog. 2009, 5, e1000608. [CrossRef]

99. Zafar, S.; von Ahsen, N.; Oellerich, M.; Zerr, I.; Schulz-Schaeffer, W.J.; Armstrong, V.W.; Asif, A.R. Proteomics Approach to Identify the Interacting Partners of Cellular Prion Protein and Characterization of Rab7a Interaction in Neuronal Cells. J. Proteome Res. 2011, 10, 3123-3135. [CrossRef] [PubMed]

100. Ramljak, S.; Schmitz, M.; Zafar, S.; Wrede, A.; Schenkel, S.; Asif, A.R.; Carimalo, J.; Doeppner, T.R.; Schulz-Schaeffer, W.J.; Weise, J.; et al. Cellular Prion Protein Directly Interacts with and Enhances Lactate Dehydrogenase Expression under Hypoxic Conditions. Exp. Neurol. 2015, 271, 155-167. [CrossRef]

101. Strom, A.; Diecke, S.; Hunsmann, G.; Stuke, A.W. Identification of Prion Protein Binding Proteins by Combined Use of Far-Western Immunoblotting, Two Dimensional Gel Electrophoresis and Mass Spectrometry. Proteomics 2006, 6, 26-34. [CrossRef]

102. Zafar, S.; Asif, A.R.; Ramljak, S.; Tahir, W.; Schmitz, M.; Zerr, I. Anchorless 23-230 PrPC Interactomics for Elucidation of PrPC Protective Role. Mol. Neurobiol. 2014, 49, 1385-1399. [CrossRef] [PubMed]

103. Faris, R.; Moore, R.A.; Ward, A.; Race, B.; Dorward, D.W.; Hollister, J.R.; Fischer, E.R.; Priola, S.A. Cellular Prion Protein Is Present in Mitochondria of Healthy Mice. Sci. Rep. 2017, 7, 41556. [CrossRef] [PubMed]

104. Miele, G.; Jeffrey, M.; Turnbull, D.; Manson, J.; Clinton, M. Ablation of Cellular Prion Protein Expression Affects Mitochondrial Numbers and Morphology. Biochem. Biophys. Res. Commun. 2002, 291, 372-377. [CrossRef]

105. Paterson, A.W.J.; Curtis, J.C.; Macleod, N.K. Complex I Specific Increase in Superoxide Formation and Respiration Rate by PrP-Null Mouse Brain Mitochondria. J. Neurochem. 2008, 105, 177-191. [CrossRef]

106. Stella, R.; Cifani, P.; Peggion, C.; Hansson, K.; Lazzari, C.; Bendz, M.; Levander, F.; Sorgato, M.C.; Bertoli, A.; James, P. Relative Quantification of Membrane Proteins in Wild-Type and Prion Protein (PrP)-Knockout Cerebellar Granule Neurons. J. Proteome Res. 2012, 11, 523-536. [CrossRef] [PubMed]

107. Becht, E.; de Reyniès, A.; Giraldo, N.A.; Pilati, C.; Buttard, B.; Lacroix, L.; Selves, J.; Sautès-Fridman, C.; Laurent-Puig, P.; Fridman, W.H. Immune and Stromal Classification of Colorectal Cancer Is Associated with Molecular Subtypes and Relevant for Precision Immunotherapy. Clin. Cancer Res. 2016, 22, 4057-4066. [CrossRef]

108. Bakkebø, M.K.; Mouillet-Richard, S.; Espenes, A.; Goldmann, W.; Tatzelt, J.; Tranulis, M.A. The Cellular Prion Protein: A Player in Immunological Quiescence. Front. Immunol. 2015, 6, 450. [CrossRef]

109. Angioni, R.; Sánchez-Rodríguez, R.; Viola, A.; Molon, B. TGF- $\beta$ in Cancer: Metabolic Driver of the Tolerogenic Crosstalk in the Tumor Microenvironment. Cancers 2021, 13, 401. [CrossRef]

110. Munn, D.H.; Mellor, A.L. IDO in the Tumor Microenvironment: Inflammation, Counter-Regulation, and Tolerance. Trends Immunol. 2016, 37, 193-207. [CrossRef]

111. Domingues, P.H.; Nanduri, L.S.Y.; Seget, K.; Venkateswaran, S.V.; Agorku, D.; Viganó, C.; von Schubert, C.; Nigg, E.A.; Swanton, C.; Sotillo, R.; et al. Cellular Prion Protein PrPC and Ecto-5'-Nucleotidase Are Markers of the Cellular Stress Response to Aneuploidy. Cancer Res. 2017, 77, 2914-2926. [CrossRef]

112. Qin, K.; Zhao, L.; Ash, R.D.; McDonough, W.F.; Zhao, R.Y. ATM-Mediated Transcriptional Elevation of Prion in Response to Copper-Induced Oxidative Stress. J. Biol. Chem. 2009, 284, 4582-4593. [CrossRef] [PubMed]

113. Boddy, A.M.; Huang, W.; Aktipis, A. Life History Trade-Offs in Tumors. Curr. Pathobiol. Rep. 2018, 6, 201-207. [CrossRef] [PubMed] 
114. Greten, F.R.; Grivennikov, S.I. Inflammation and Cancer: Triggers, Mechanisms, and Consequences. Immunity 2019, 51, 27-41. [CrossRef]

115. Taniguchi, K.; Karin, M. NF-KB, Inflammation, Immunity and Cancer: Coming of Age. Nat. Rev. Immunol. 2018, 18, 309-324. [CrossRef] [PubMed]

116. Wu, G.-R.; Mu, T.-C.; Gao, Z.-X.; Wang, J.; Sy, M.-S.; Li, C.-Y. Prion Protein Is Required for Tumor Necrosis Factor $\alpha$ (TNF $\alpha$ )Triggered Nuclear Factor KB (NF-KB) Signaling and Cytokine Production. J. Biol. Chem. 2017, 292, 18747-18759. [CrossRef]

117. Assi, K.; Mills, J.; Owen, D.; Ong, C.; St Arnaud, R.; Dedhar, S.; Salh, B. Integrin-Linked Kinase Regulates Cell Proliferation and Tumour Growth in Murine Colitis-Associated Carcinogenesis. Gut 2008, 57, 931-940. [CrossRef] [PubMed]

118. Pammer, J.; Cross, H.S.; Frobert, Y.; Tschachler, E.; Oberhuber, G. The Pattern of Prion-Related Protein Expression in the Gastrointestinal Tract. Virchows Arch. Int. J. Pathol. 2000, 436, 466-472. [CrossRef]

119. Petit, C.S.V.; Barreau, F.; Besnier, L.; Gandille, P.; Riveau, B.; Chateau, D.; Roy, M.; Berrebi, D.; Svrcek, M.; Cardot, P.; et al. Requirement of Cellular Prion Protein for Intestinal Barrier Function and Mislocalization in Patients with Inflammatory Bowel Disease. Gastroenterology 2012, 143, 122-132.e15. [CrossRef]

120. Cai, J.; Zhang, N.; Zheng, Y.; de Wilde, R.F.; Maitra, A.; Pan, D. The Hippo Signaling Pathway Restricts the Oncogenic Potential of an Intestinal Regeneration Program. Genes Dev. 2010, 24, 2383-2388. [CrossRef]

121. Johnson, R.; Halder, G. The Two Faces of Hippo: Targeting the Hippo Pathway for Regenerative Medicine and Cancer Treatment. Nat. Rev. Drug Discov. 2014, 13, 63-79. [CrossRef] 